\title{
A Critical Review of Professional Socialization Models for Medical Students
}

\author{
Shahram Yazdani ${ }^{1}$, Homa Sadeghi Avval Shahr ${ }^{2}$, Leila Afshar ${ }^{3}$
}

\begin{abstract}
Background \& Aims: Professionalism is the underlying factor in strengthening the social contract between professions and the society. Failure to adhere to this principle in healthcare providers (including nurses) reduces the quality of patient care and endangers community health, while also diminishing public trust and weakening the social image of healthcare professions. In recent decades, researchers of health science education have focused on the nature of professionalism and planning for training in this regard in order to achieve this important outcome in health science graduates. Despite the applications of the study results and the efforts to train students on the basic concepts of professional ethics, the expected outcomes have not yet been realized in terms of the performance of graduates. Today, numerous researchers believe that achieving professionalism is not possible merely through education and the evaluation of its principles, and the required competencies should also be cultivated to facilitate the process of professional socialization, so that a proper professional identity could be attained in medical science graduates. However, further studies should be focused on the top of Miller's pyramid (Does) pertains to the process of developing competencies and their components and has reached the stages of developing a competency-based curriculum, along with the formation of a professional identity, which is equivalent to the "Is" part added to the Miller's model by Cruess et al. (2016). In a study in this regard, the concept of professional socialization was analyzed, and professional identity was introduced as the main outcome of this process. The present study aimed to critically review the current literature regarding socialization and the development of professional identity in health science students.

Materials \& Methods: This critical review was conducted based on the Carnwell and Daly structure, which consists of six steps, including determining the objectives of the critical literature review, defining the scope of the review, identifying the sources of relevant information, literature review, writing the review, and applying the literature to the proposed study. At the stage of review writing, we followed the three steps proposed by Schutz. Initially, a systematic search was performed to obtain the available conceptual models and frameworks of socialization and professional identity formation in primary scientific databases, such as EBSCO CINAHL, Web of Science, Eric, PubMed, Scopus, and Google Scholar, using relevant keywords with "OR" and "AND" to combine the main concepts. The article search had no time limit until 2019. The eligibility criteria for article selection were proposing a model/conceptual framework, medical sciences, free access, and publication in English language. The exclusion criteria were duplicates and the experimental studies aimed at the measurement, comparison or production of tools. In the second phase of the search and to obtain citations and criticisms for each selected conceptual model/framework, the key concepts of each was systematically searched in the aforementioned databases using "AND" in combination with concepts such as "Criticism, Problems, Challenges, Advantages, Disadvantages". To ensure access to all the possibly relevant reviews, all the citations to each model were tracked through Google Scholar.

Results: In total, 2,112 articles were retrieved in the first stage of the search in terms of the title, followed by the abstract. After reviewing the full texts of the selected articles, nine articles were selected based on the research criteria in the fields of nursing, social work, medicine, paramedicine, and student affairs. These articles were categorized in terms of the study design, model type, model focus, and outcomes. Following that, the selected

\footnotetext{
1. Virtual School of Medical Education and Management, Shahid Beheshti University of Medical Sciences, Tehran, Iran.

2. Medical Education, Virtual School of Medical Education and Management, Shahid Beheshti University of Medical Sciences, Tehran, Iran

${ }^{3}$. Department of Medical Ethics, Shahid Beheshti University of Medical Sciences, Tehran, Iran (Corresponding author)
} Tel: +982188773521 Email: leilaafshar@sbmu.ac.ir
\end{abstract}


models were examined chronologically based on the three steps proposed by Schutz, which are the description of the model by its providers, providing the viewpoints of their critics/promoters (if any), and presenting the critical views of the authors of the article. After the analysis of the elements and content/structure of the conceptual models/frameworks, the key concepts of each model were extracted and presented in a table. The studied conceptual models and frameworks consisted of four categories (descriptive, normative-descriptive, causalexplanatory, and descriptive-prescriptive), which described the process of socialization and the role of the influential factors. Some of the findings were mainly focused on the cognitive and psychological dimensions, as well as the social dimension of the process in some cases. In the cases where both the psychological (internal) and social dimensions (external) of the process were considered, a structural approach was not observed regarding the elements and components of each dimension. In addition, the assessment of the content and description of the models revealed various theoretical approaches to this process, some of which were based on a functional structuralism approach and emphasized the role of organizational factors. The other cases involved the cognitive and interactive dimensions and the role of student agencies in this process, as well as the combination of the two approaches. In addition to the role of institutional factors, the active role of students and the impact of interactions were also discussed with regard to the development of professional identity without determining its dimensions and components. The key concepts extracted from the selected models in the present study could be classified into two psychological and social dimensions. The psychological dimension could be classified as cognitive (principles, values, and professional norms), affective (descriptive [sense of belonging to the profession], evaluative [self-confidence], and normative [attitude toward the profession]), and volitive (job motivation). Similarly, the social dimension could be categorized into the communicative domain (effective professional communication), cohesive domain (mutual respect and commitment), and operative domain (professional behavior and effective role performance).

Conclusion: Presenting the components of professional identity based on psychological and social dimensions could lay the groundwork for designing a comprehensive, static, structural model of professional identity for medical students, thereby resulting in the development of structured interventions for the management of professional identity formation in further investigations.

Keywords: Professional Identity, Professional Socialization, Medical Students, Conceptual Model, Conceptual Framework

\section{Conflict of Interest: No}

How to Cite: Yazdani SH, Sadeghi Avval Shahr H, Afshar L. A Critical Review of Professional Socialization Models for Medical Students. Iran Journal of Nursing. 2020; 33(126):82-102.

Received: 17 Jul 2020

Accepted: 16 Oct 2020 


\title{
مرورى نقادانه بر مدلهاى جامعهيذيرى حرفهاى دانشجويان علوم يزشكى
}

\author{
شهرام يزدانى '، هما صادقى اول شهر '، ليلا افشارّ
}

جكيده

زمينه و هدف: حرفه ايى گرايى عامل اصلى و زيربنايى تحكيم قرارداد اجتماعى بين حرفه و جامعه است. فقدان توجه و يايبندى به اين اصل در بين ارائه

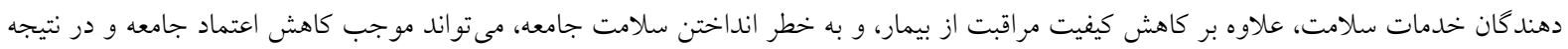

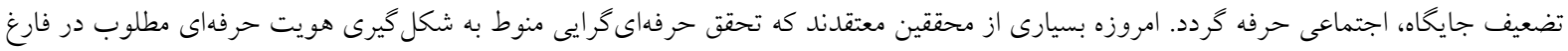

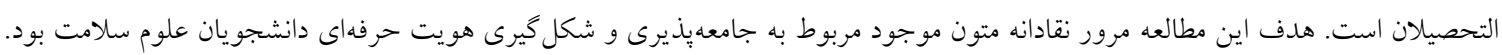

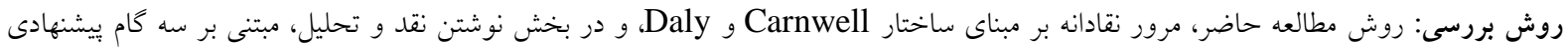
Schutz

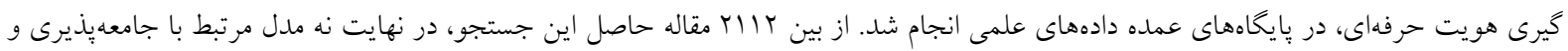

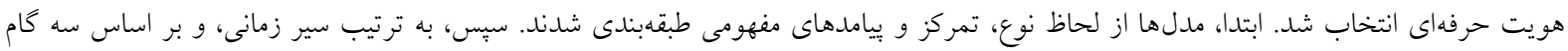

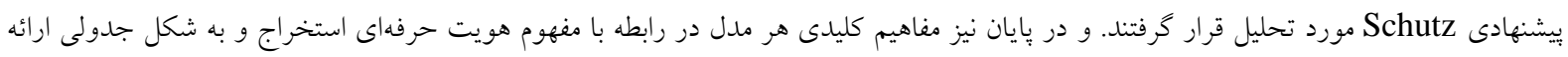

يافتها: مفاهيم كليدى استخراج شده از مدلهاى منتخب در دو بعد روانى، و اجتماعى قابل طبقبندى است. در بعد روانى، سه حيطهى شناختى

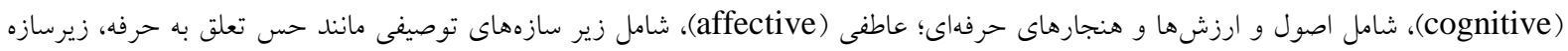

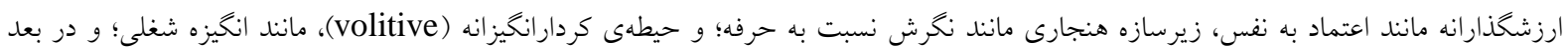

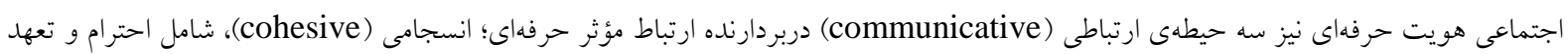

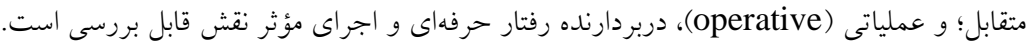

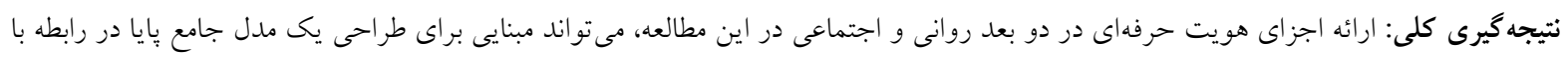
هويت حرفهاى دانشجويان علوم يزشكى در مطالعات آينده، و نيز طراحى مداخلات ساختارمند جهت مديريت شكل گيرى هويت حرفهاى باشد. كليد وازهها: هويت حرفهاى، جامعه يذيرى حرفهاى، دانشجويان يزشكى، مدل مفهومى، جارجوب مفهومى تعارض منافع: ندارد تاريخ دريافت: 99/そ/TV تاريخ بذيرش: 99/V/TO 
به عضويت در اين جوامع حرفهاى، در طى دوره رسمى مقدمه آموزش براى حرفه با آن مواجهاند.

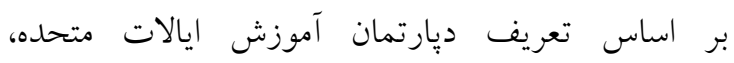

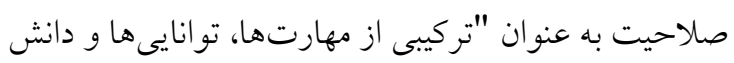

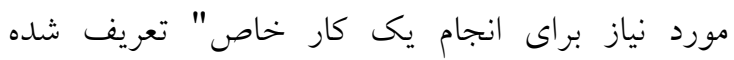

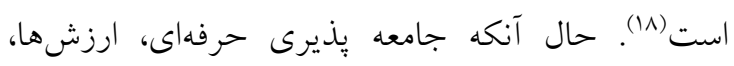

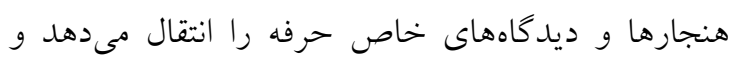
زمينه مشتركى براى شكل دادن به شيوههاى انجام كار، و امكان برقرارى ارتباط مؤثر با اعضاى حرفه را فراهم

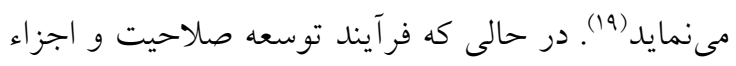

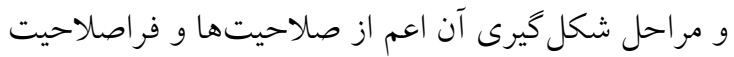
ها كه تشكيل دهنده بخش بالايى هرم Miller، يعنى "انجام

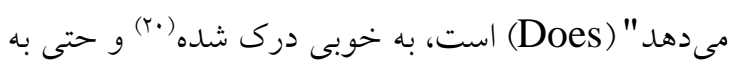
مراحل تلدوين جارجوب ارزيابى اجراى برنامه درسى به آموزشى مبتنى بر صلاحيت نيز رسيده است (r) فروبن فرآيند

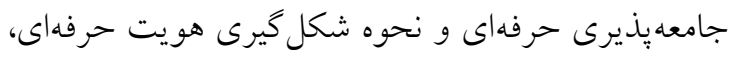

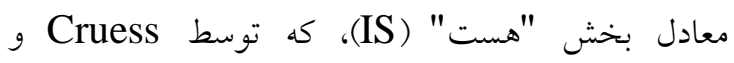

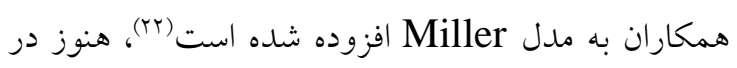
هالهاى از ابهام بوده، و نيازمند مطالعه و بررسى بيشترى هـان

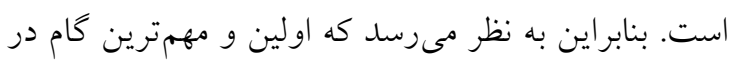

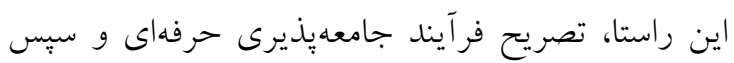

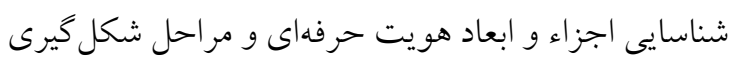
آن باشد. بنابراين پيس از گام اول كه تحليل مفهوم جامعهد يذيرى حرفهاى است و در مطالعه ديخرى بـ به آن آن

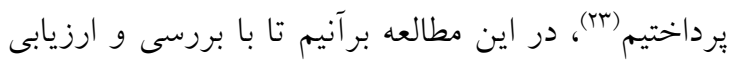

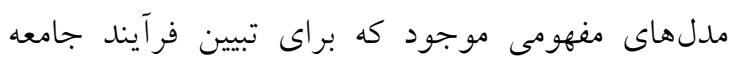

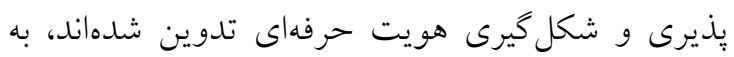
درك عميق ترى از اين فرآيند دست يابيم. هدف اين مطالعه تعيين اجزا و ابعاد هويت حرفهاى از طريق مرور نقادانه مدل هاى مفهومى جامعه يذّيرى و شكل گيرى هويت حرفه منش حرفهاى (Professionalism)، سنگ زير بنا و عامل اصلى تحكيم و تداوم قرارداد اجتماعى بين حرفه و

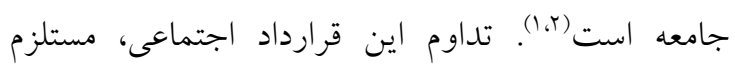
برآورده نمودن انتظارات جامعه، و حفظ اعتماد جامعه به إنه

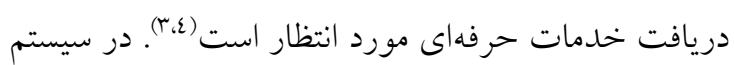
درمانى فعلى، تعدد وظايف كاركنان تيم سلامت و و

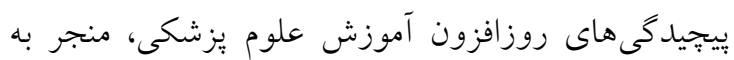

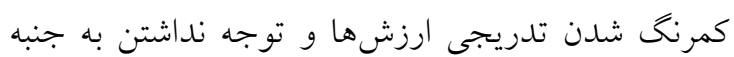

هاى انسان كرايانه حرف علوم سلامت گرديده است (0) در طى جند دهه اخير، بروز رفتارهاى غير حرفهاى و و

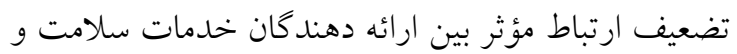
دريافت كندكان اين خدمات كه تبعات آن كاهش كيفيت مراقبت از بيمار ان و مورد تهديد قرار كرفتن سلامت جامعه

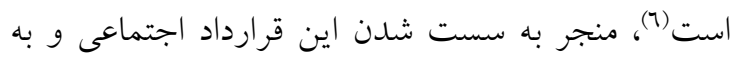
تبع آن تضعيف نسبى جايگاه اين حرف در جامعه، گرديده

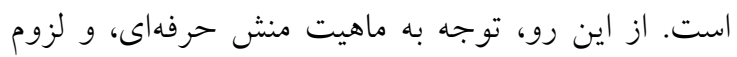

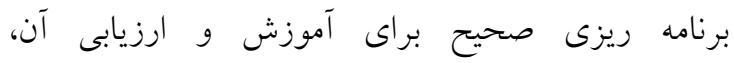

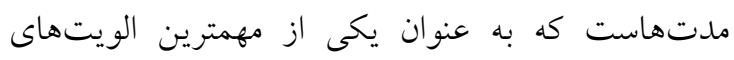

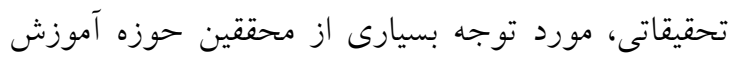

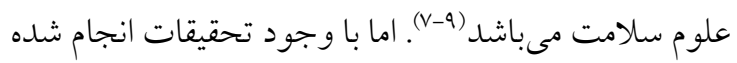

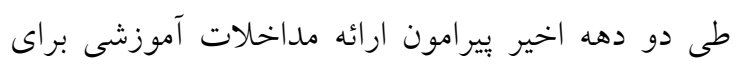

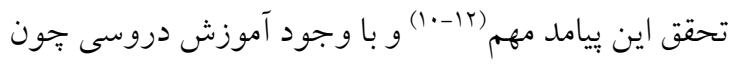

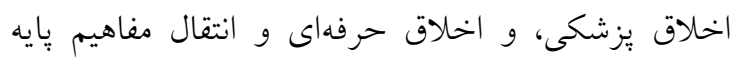

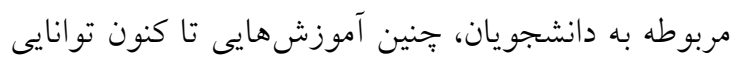
تضمين درونى نمودن ارزشهاى حرفهاى را نداشته (rا)، و و

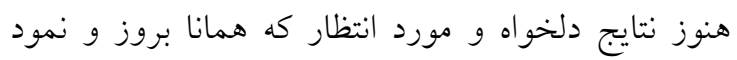

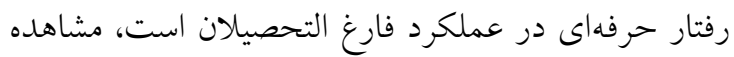

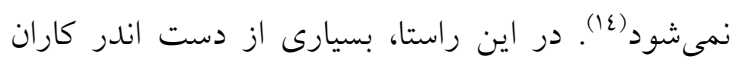

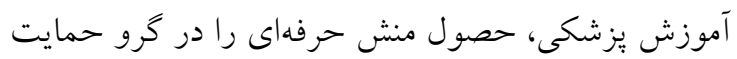

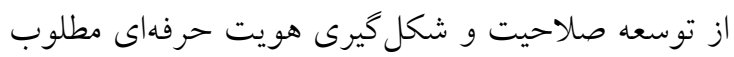

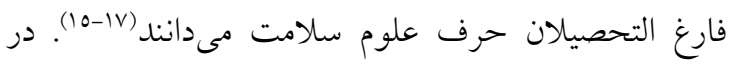
حقيقت، توسعه صلاحيت و جامعه بذذيرى حرفهاى، دو فرآيند عمده زيربنايى هستند كه دانشجويان و علاقمندان 
دسترسى نداشتن به متن كامل و مقالات تجربى با هدف

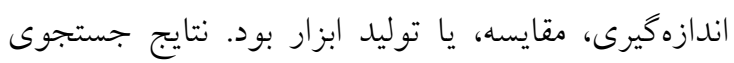

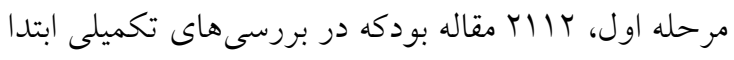
غربالكرى درسطح عناوين براى حذف مقالات غير مرتبط،

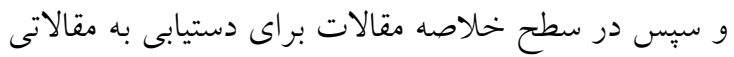

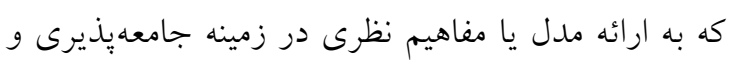

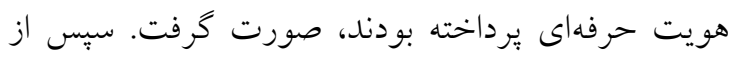

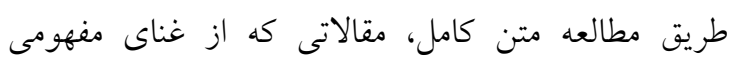
بيشترى برخوردار بودند و دربردارنده اجزاء و مؤلفههاى مهن مفهومى بيشترى در رابطه با جامعه يذيرى و هويت حرفه بردي اي بودند، انتخاب شدند (شكل شماره ()). در فاز دوم جستجو براى دسترسى به نقدهاى موجود در متون در خصوص تك تك مدلها و نظريههاى انتخاب شده، كلمات كليدى مفاهيم اصلى مدلها و نظريهها با استفاده از "AND" در تركيب با مفاهيمى خجون: "Critique, Problems, Challenges, short comes, advantages, disadvantages" هاى داده مذكور مورد جستجو قرار كرفت. همجنين در

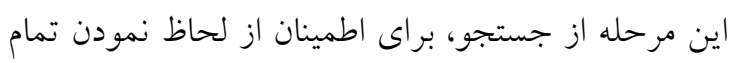

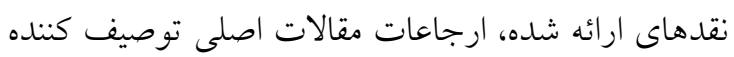

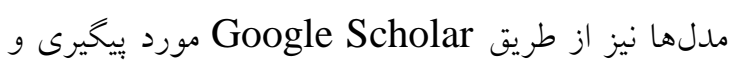

$$
\text { برسى قرار خرفت. }
$$

تجزيه و تحليل مفهومى يك فرآيند جامع و دقيق است. بنابراين براى كاهش خطر تعصب محققان در اين فرآيند

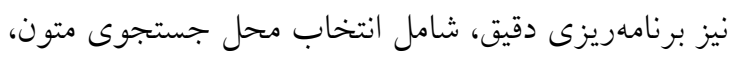

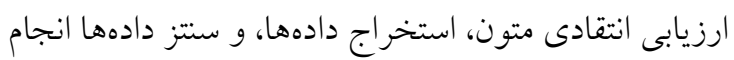

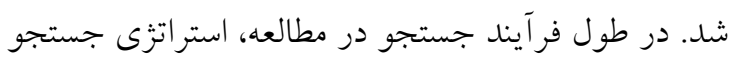
به وضوح مستند شده و كلمات كليدى و معيارهاى ورود و خروج تعيين شد. اين رويكرد تضمين مى كند كه تمام

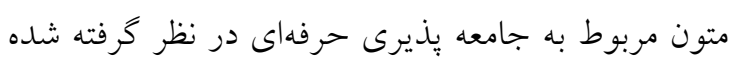
است. همجنين براى كسب اطمينان از اعتبار داخلى مطالعه، از نظرات يك منتقد مستقل نيز در رابطه با معيارهاى ورود به مطالعه نهايى و ارزيابى انتقادى مطالعه كمى كرفته شد. اعتبار اين مطالعه نيز با انجام جستجوى جامع تضمين

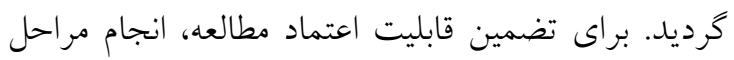

اين مطالعه بر مبناى روش مرور نقادانه انجام شد. نقد

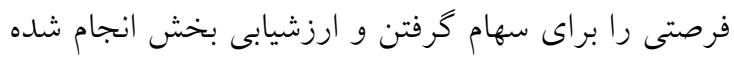

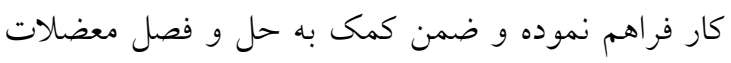
مكاتب فكرى رقيب، مىتواند سكوى يرتابى براى مرحله وحنه

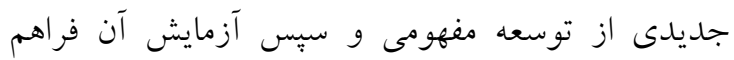
نمايد (rع). لذا مطالعه حاضر به روش مرور نقادانه، بر مبناى ساختار Carnwell تعيين اهداف مرور نقادانه متون، تعريف حوزه و حدود

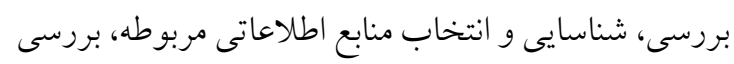

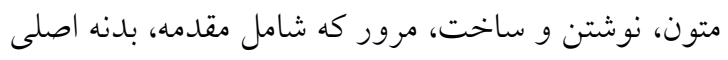
و نتيجه كيرى و كاربرد متون براى مطالعه ييشنهاد شده

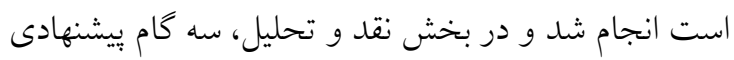
Schutz ، نقل شده توسط Atkins و همكاران دنبال شد:

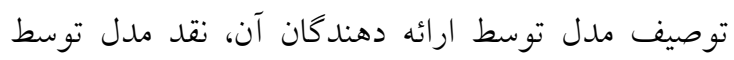
ديخران، و نقد مدل توسط نويسنده مرور نقادانه (TT). بر اين اساس، با توجه به هدف اين مطالعه كه تعيين اجزا

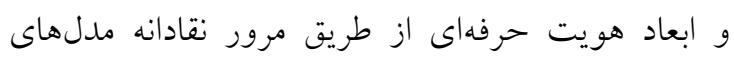
مفهومى جامعه بذيرى و شكل كيرى هويت حرفهاى است،

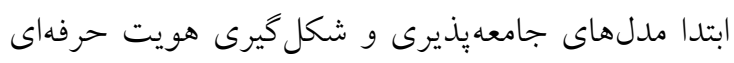
در حوزه علوم يزشكى، بدون اعمال محدوديت زمانى تا تاني

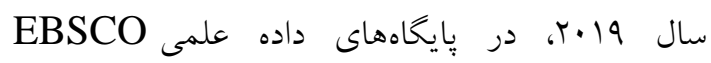
CINAHL, EBSCO Education Research, , Web of Science, Eric, Pub Med ,Scopus Google Scholar استفاده از”AND“" و "OR" براى تركيب كردن مفاهيم اصلى، مورد جستجوى سيستماتيك قرار گرفت: "professional socialization", "professional identity formation", "conceptual model", "conceptual theory", "conceptualization", "conceptual framework", "medical students" معيارهاى انتخاب متون بر اساس ميزان ارتباط با اهداف

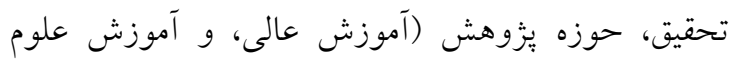

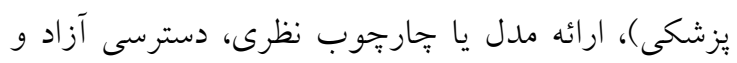

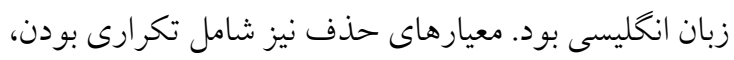


اين مطالعه يُ از تأييد بيش نويس آن توسط شوراى اساتيد راهنما و مشاور اين طرح، كه هر دو از بصيرت و

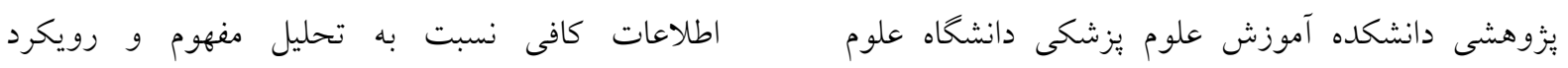

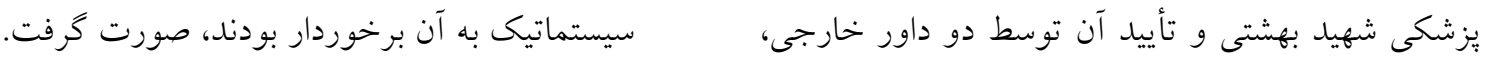

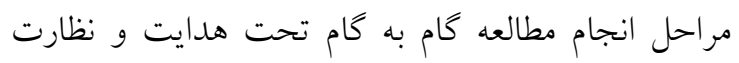

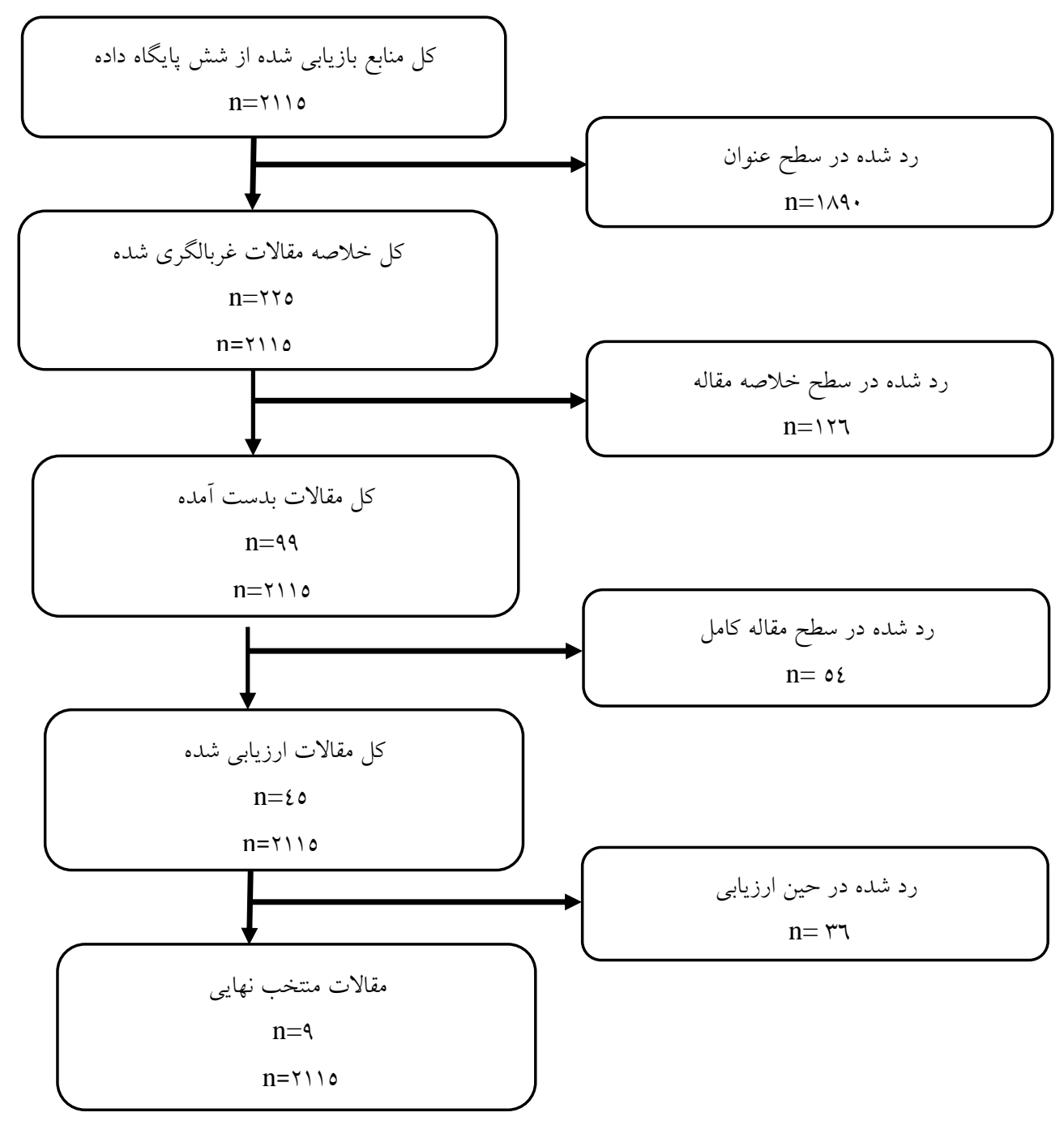

شكل شماره (: استراتثى جستجو

مسيرى مخاطره آميز؟(19)؛ جارجوبى مفهومى براى جامعه

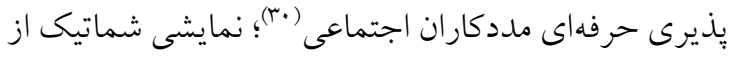
از بين مقالات بررسى شده، نه مدل مرتبط با جامعه يذّيرى

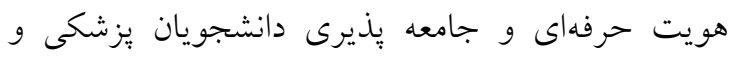
حرفهاى مشخص شد. اين مدلها عبارتند از:

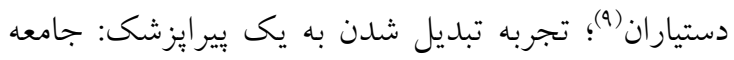

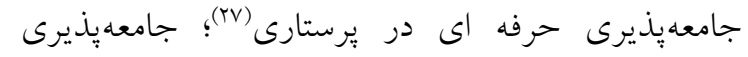

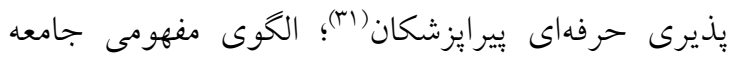

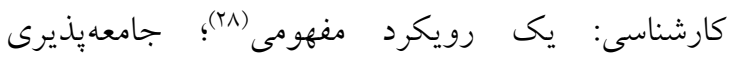
يذيرى حرفهاى در برنامه آمادكى دانش آموختخان رشته دانشجويان تحصيلات تكميلى و حرفهاى در آموزش عالى: 
از اين روابط دفاع مى كند ('^). مدل توصيفى، بديدهها، وقايع و فر آيندها را همانغونه كه هستند توصيف مى كند (ra)، اما

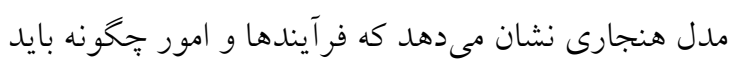

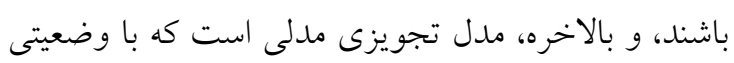

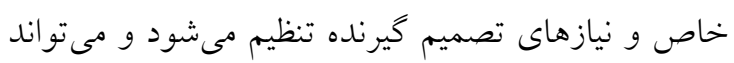

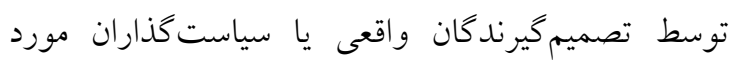

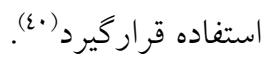

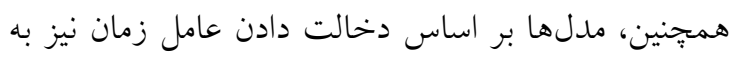

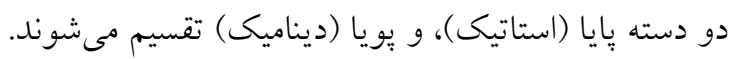
در مدلهاى بايا، عامل زمان به صراحت مورد توجه قرار

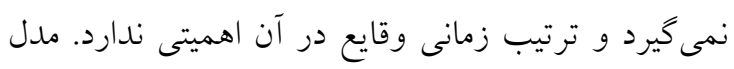

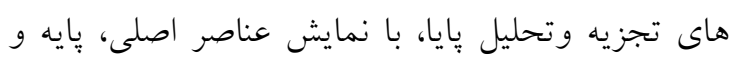
اساس مدلهاى تحليلى يويا را فراهم مى كنند (1).

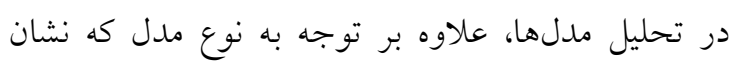

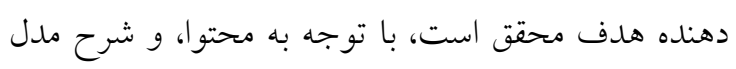

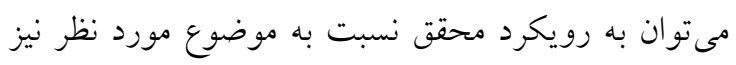

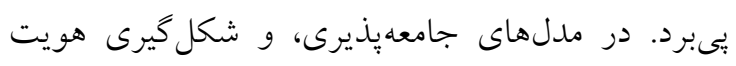

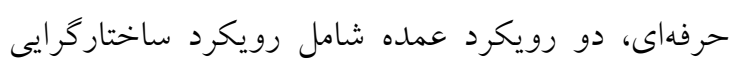

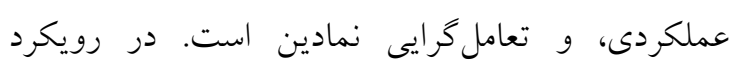
ساختار گر ايى عملكردى، جامعهليذيرى به عنوان فرآيند القاء ارزشها و هنجارهاى حرفه به اعضاى جديد، و يكيارجه

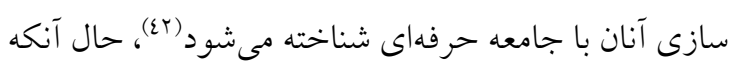

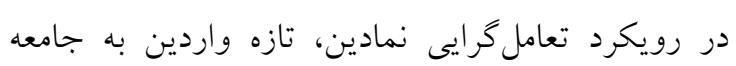

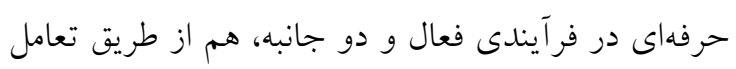

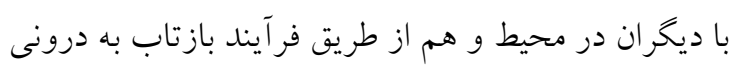
سازى ارزشها و هنجارهاى حرفهاى و ايجاد هويت حرفه

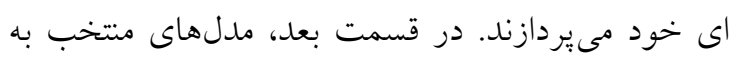
ترتيب سير زمانى، و مبتنى بر سه كام يبشنهادى Schutz

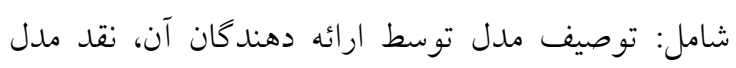
توسط ديخران، و نقد مدل توسط نويسنده مرور نقادانه

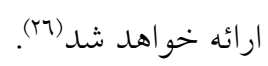

خدمات دانشجويى (rr)؛ بررسى انتقال دانشجويان يزشكى

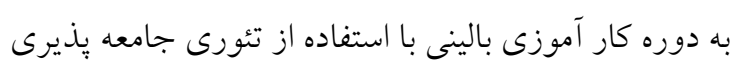

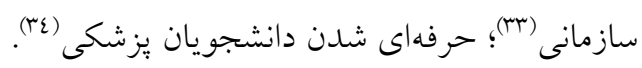

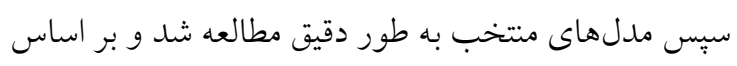

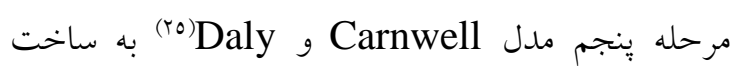
مرور، شامل مقدمه، بدنه اصلى و نتيجه گيرى برداخته شد. مقدمه مرور نقادانه حصول بيشرفت علمى در هر رشتهاى حاصل هم انديشى مرور نعادله

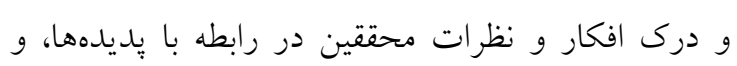

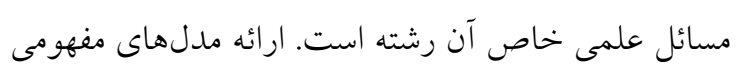

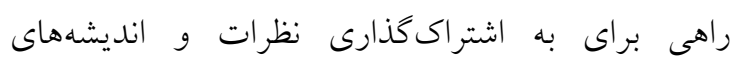

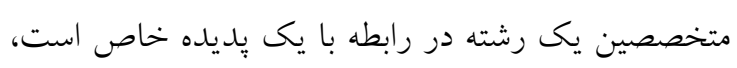

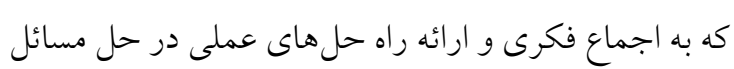
مربوطه كمك مى كند (ro). مدل مفهومى مجموعهاى از مفاهيم نسبتاً انتزاعى و تعاريف كمبن

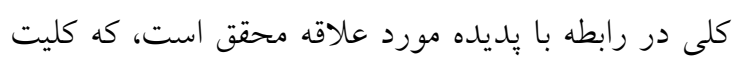

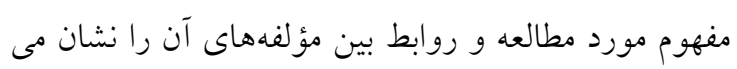
دهد. مدلهاى مفهومى حاصل مشاهدات تجربى و بينش

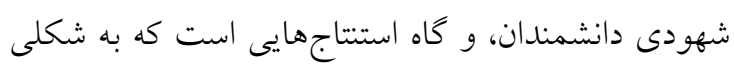

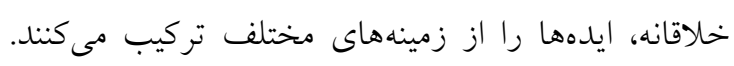

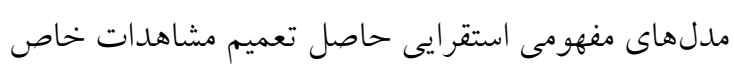

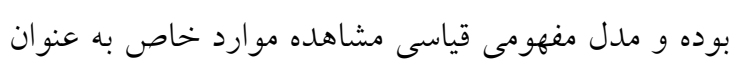

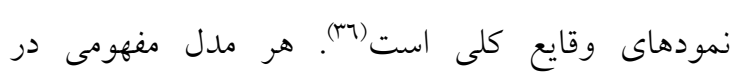

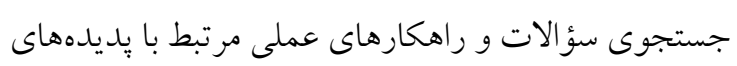

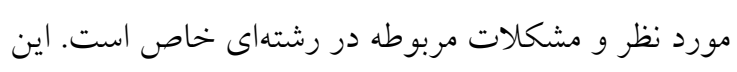

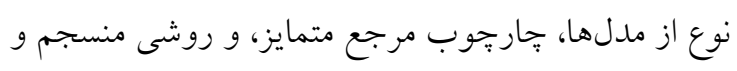

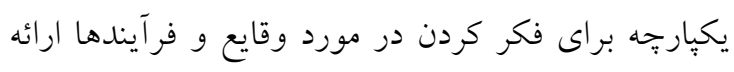

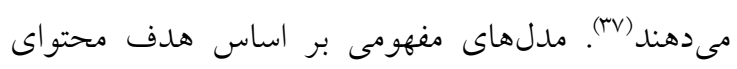

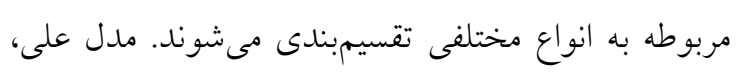

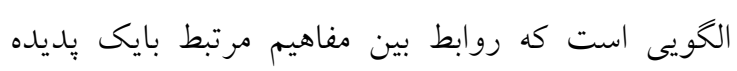

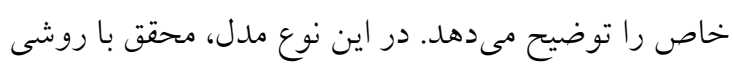

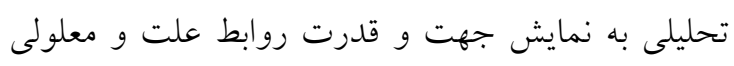

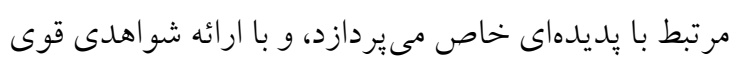


عوامل تأثير كذار، و ويامدهاى فرآيند، منجر به دشوارى درى آن كرديده است. به همين ترتيب هر يك از اجزاى

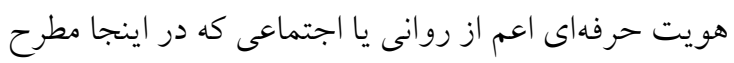

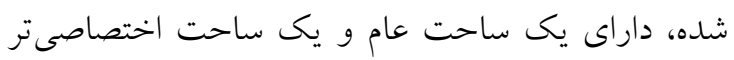

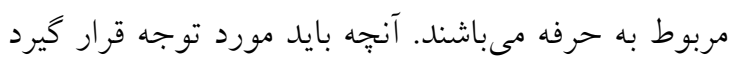

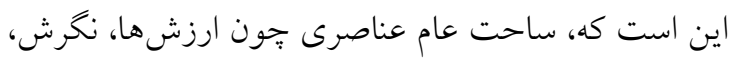

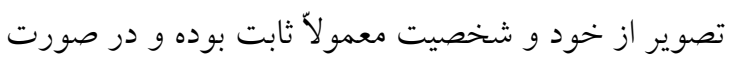

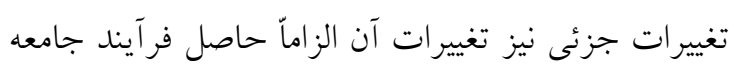

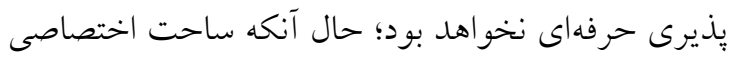

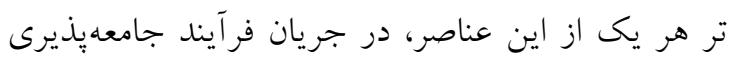

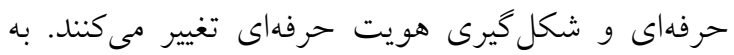

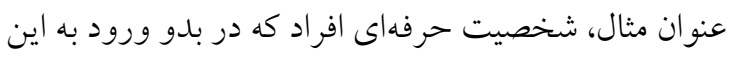

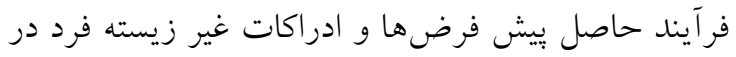

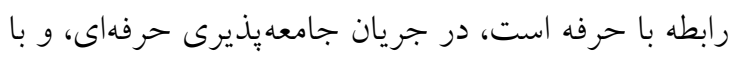
كسب تجارب زيسته در اين فرآيند به شخصيت حرفهاي

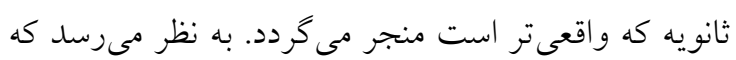
Edens

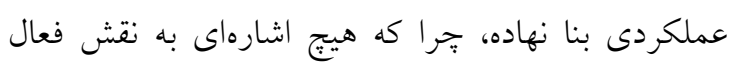

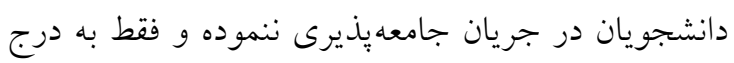
ويزّكى هاى زمينهاى آنان اكتفا نموده است.

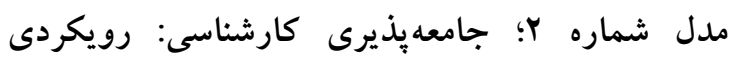

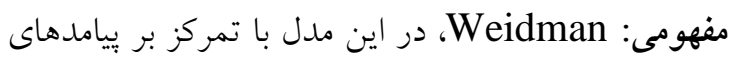

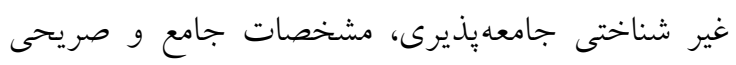

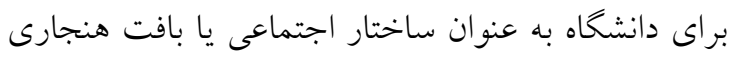

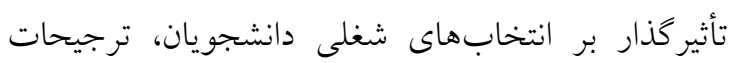
سبك زندگى و آرمانهاى شغلى آنان ارائه مى دهد، و علاوه بر برداختن به متغيرهاى بى شمار داخل دانشكاه به تأثيرات

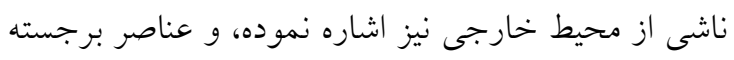

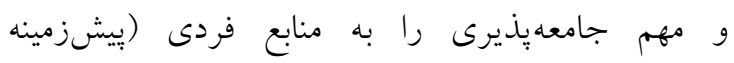

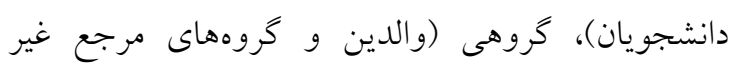
دانشخاهى) و سازمانى (ساختار علمى و اجتماعى دانشعاه)

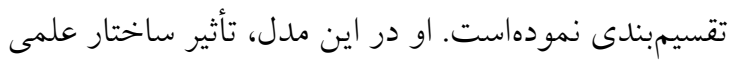

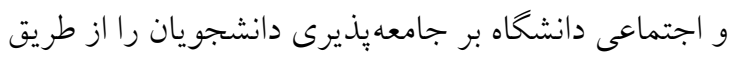

بدنه مرور نقادانه مدل شماره 1؛ جامعه يذيرى حرفهاى در يرستارى: اين

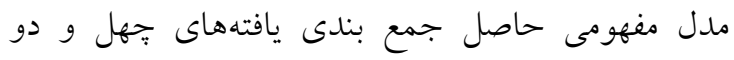

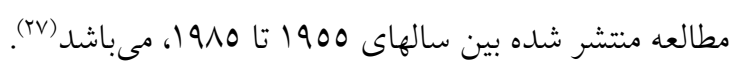
Edens

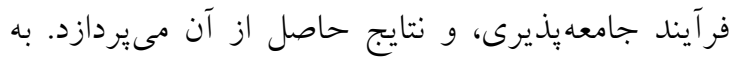

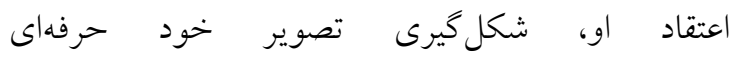
در دانشجويان، هدف (Professional self-image)

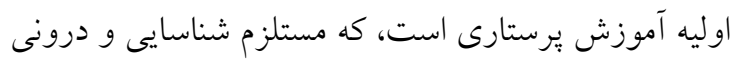

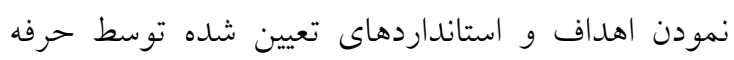

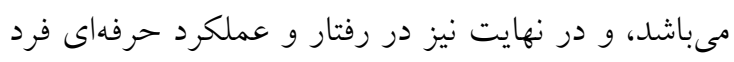

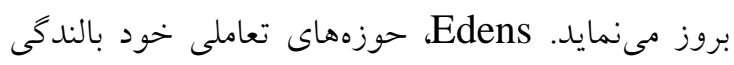

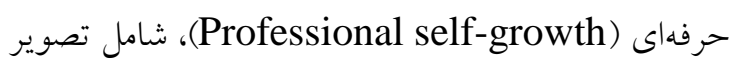

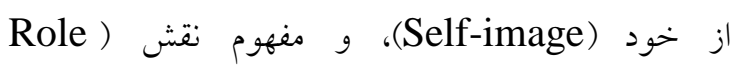

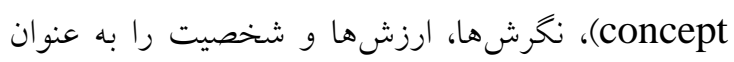

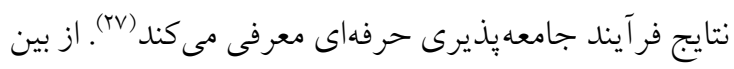

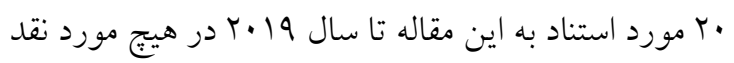
يا توصيهاى در رابطه با ارتقاء مدل ارائه نشده است.

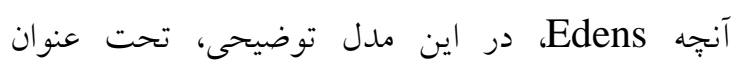

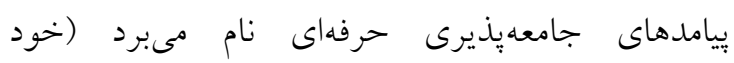

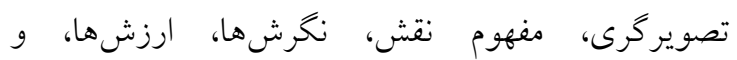

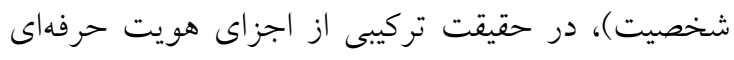
است، كه به قول Cruess و همكاران، در طول فرآيند

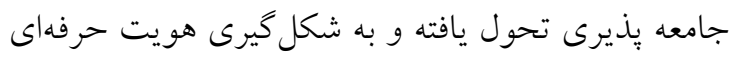

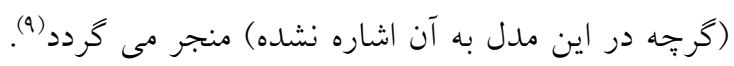

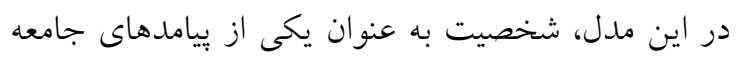
يذيرى حرفهاى معرفى شده است در حالى كه به اعتقاد

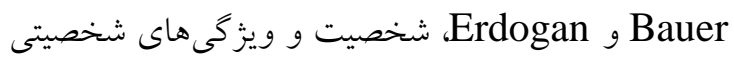

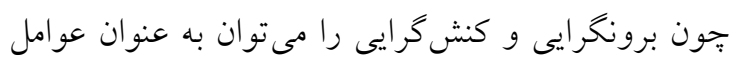

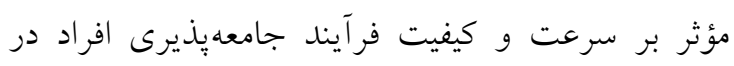

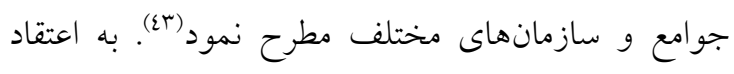

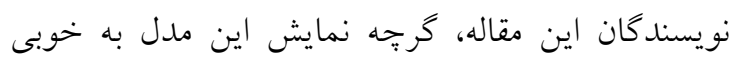

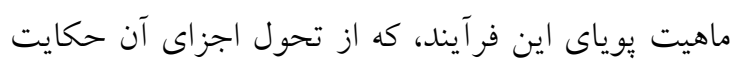

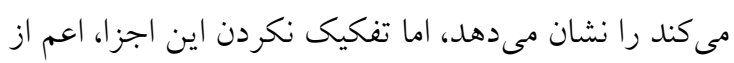


"به نظر مىرسد كه اين بيامدها بيشتر تابعى از ويزگكىها،

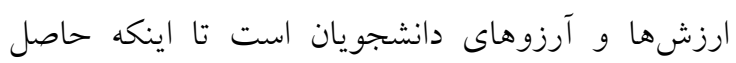

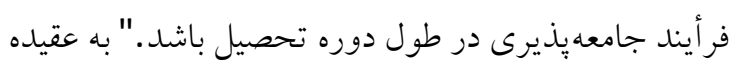

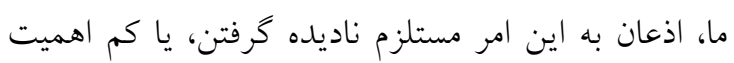

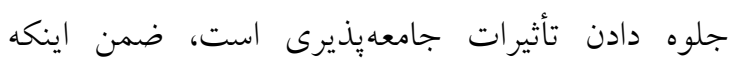
نويسنده، منبع تنين استتاجى را نيز، طرح نكرده است.

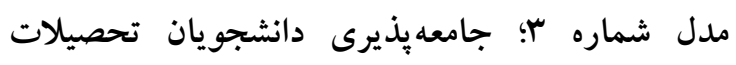
تكميلى و حرفهاى در آموزش عالى: مسيرى مخاطرهآميز؟ Weidman و همكاران، در ادامه مطالعات خود در زمينه

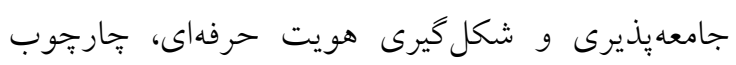

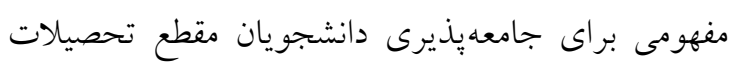

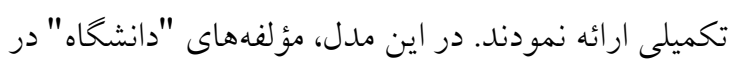

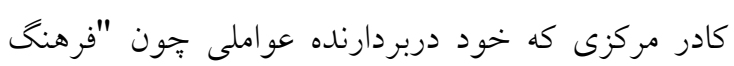

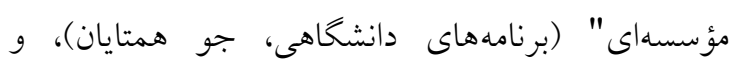

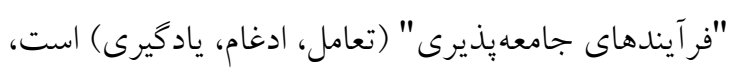

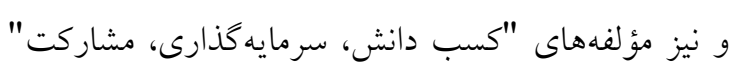

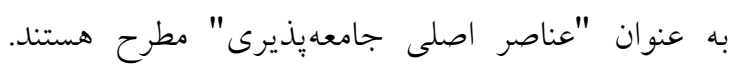

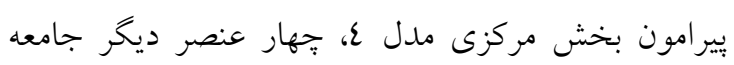
"يذيرى، شامل "دانشجويان آينده" (بيشزمينه، مئه استعدادها)،

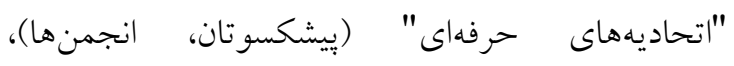
"اجتماعات شخصى" (خانواده، دوستان، كارفرمايان) و "يزشكان حرفهاى تازهكار" قرار دارد. قرار دادن اين مؤلفه

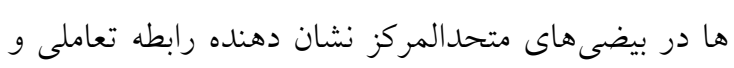
غيرخطى بين اين اجزا است (ra).

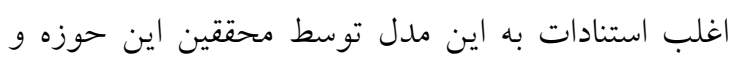
بخصوص يزوهشخران علاقمند به بررسى تجربيات دوره

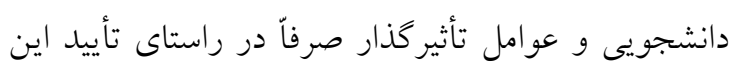

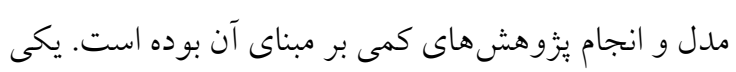

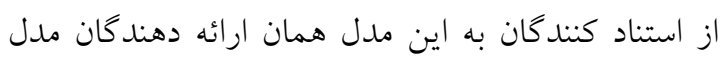

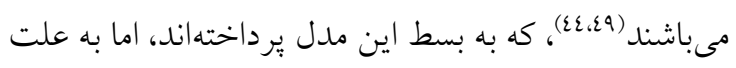

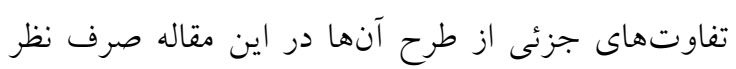

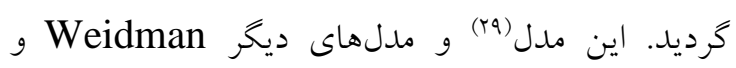

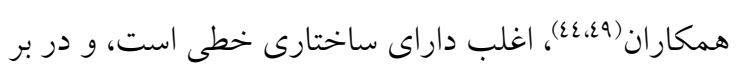
دارنده سابقه و زمينهاى قبلى دانشجويان، و تجربيات، و و
ساز و كار فرآيندهاى بين فردى و درون فردى، به تصوير كثيده شده است (YN)

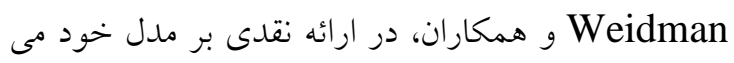

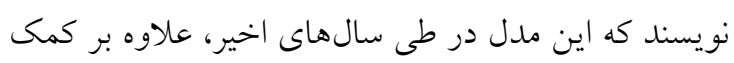

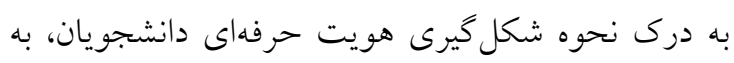

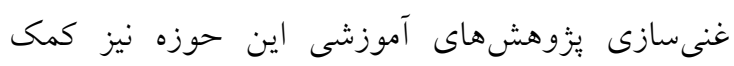

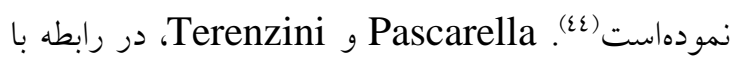
محتوا و نوع اين مدل، آن را نوعى مدل على كه در بردارنده

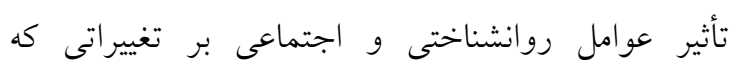

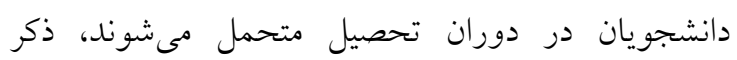
مى كنند (20). يكى از نقاط قوت مدل Perenzini Pascarella جامعهيذيرى Weidman، را توجه به تأثيرات بالقوه عوامل خارجى بر فر آيند جامعهيذيرى ذكر مى كنند كه نشان

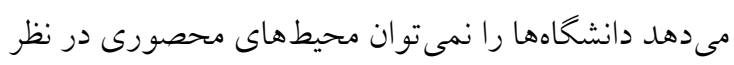

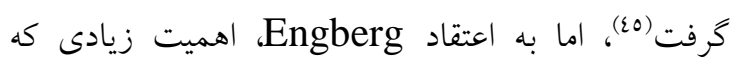
نويسنده بر ادامه نقش جامعهيذيرى والدين، حتى در دوران

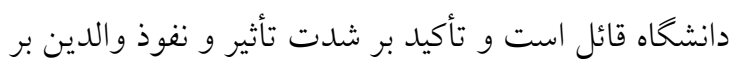

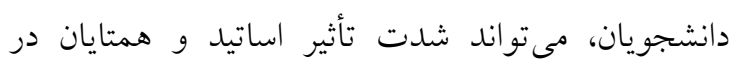
دانشكده را تحت تأثير قرار دهد (i7). Ozaki

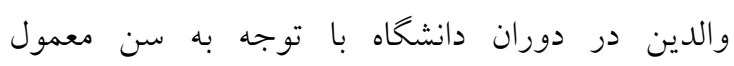

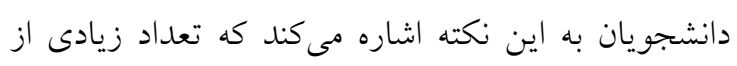

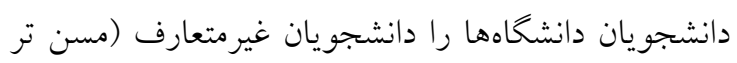
و شاغل) ، كه بسيارى خود داراى فرزند مىباشند، تشكيل

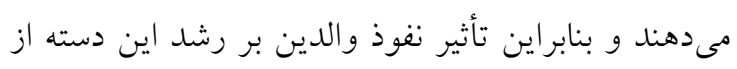

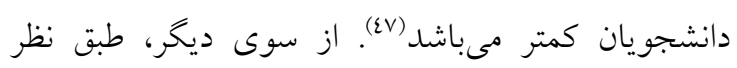

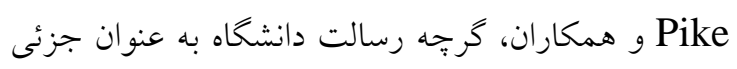

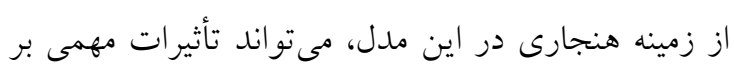
تجربه جامعهيذيرى دانشجويان اعمال نمايد، اما اندازه

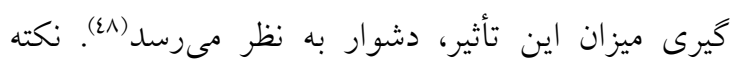

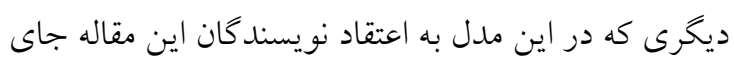
بحث دارد اين است كه نويسنده در شرح بخش بين ميامدهاى

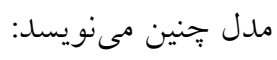


هنجارهاى حرفه) و نيز "ساختار" (ساختار آموزشى

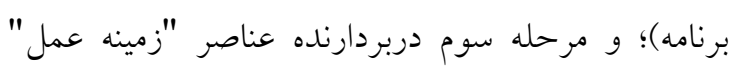

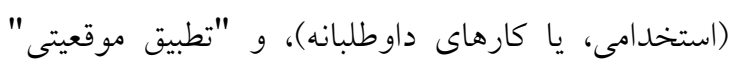

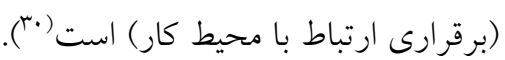
Wheeler

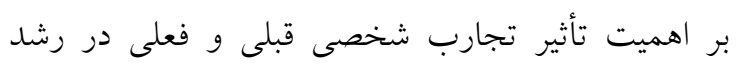
هويت حرفهاى دانشجويان مددكارى اجتماعى تأييد نمود

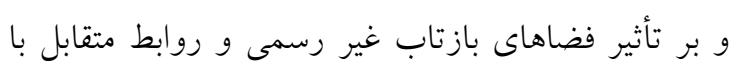

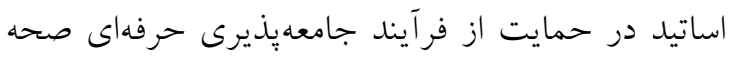

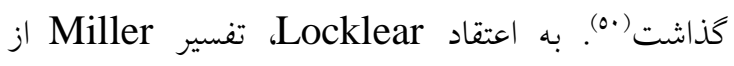
فرآيند جامعه بذيرى حرفهاى، به عنوان يكى فر آيند تكوينى

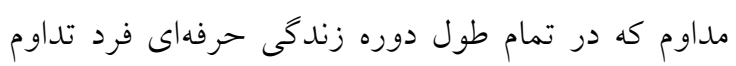

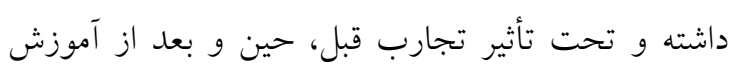

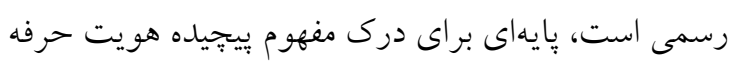

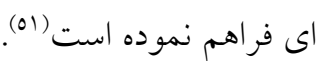

با توجه به اينكه، طبق اظهار Domenici و Dو Donno

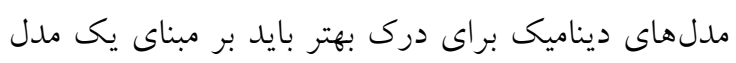

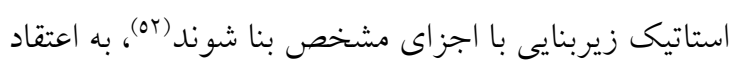

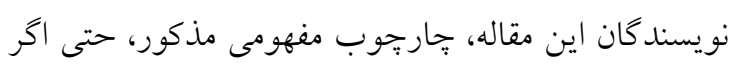

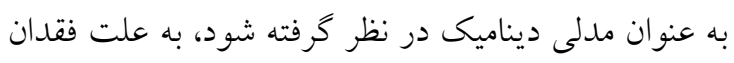

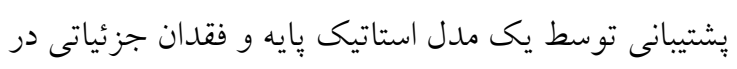

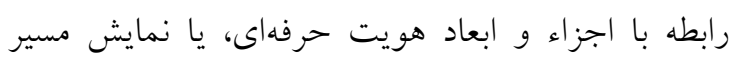

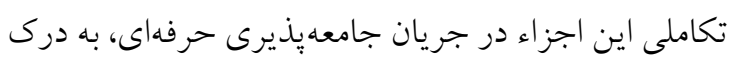
عميق مؤلفههاى اصلى اين فر آيند كمك ننموده و صرفاً به آنه عنوان يك جارجوب توصيفى كه به تعريف اين سه مرحله اكتفا نموده، قابل درى است. مدل شماره 0؛ نمايشى شماتيك از هويت حرفهاى و جامعهيذيرى دانشجويان بزشكى و دستياران: Cruess

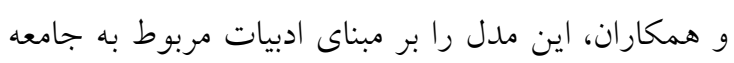

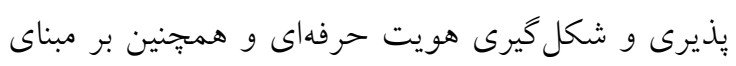

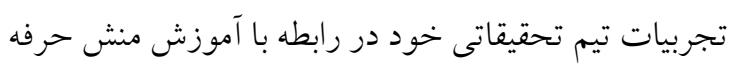

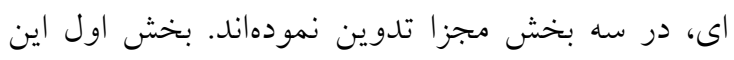

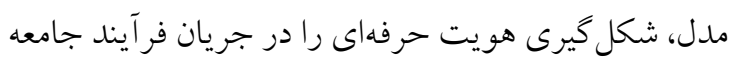

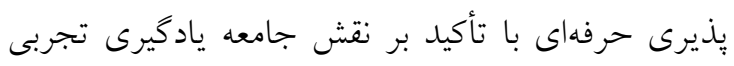

بيآمدهاى آنان است، اما به كَته Ozaki، آنجه اين مدل را

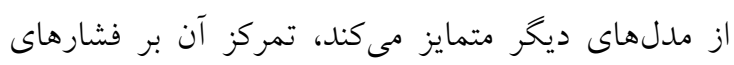

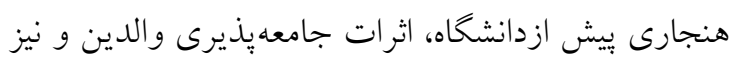

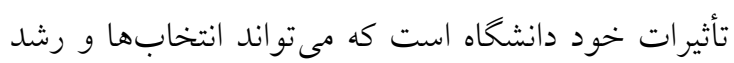

دانشجويان را تحت تأثير قرار داده و محدود كند (عV).

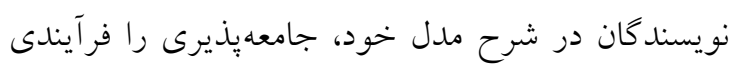

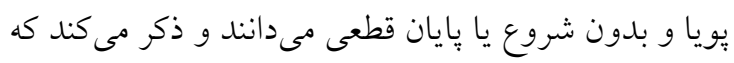

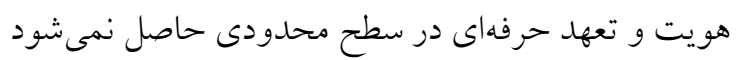

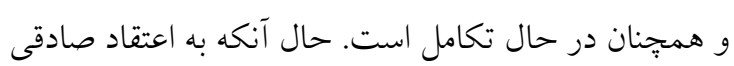
و همكاران، جامعهيذيرى حرفهاى، بخشى از فر آيند مادام

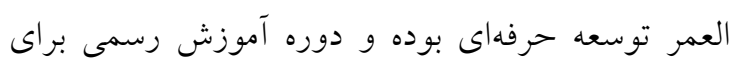

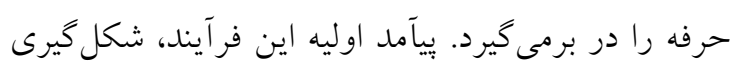

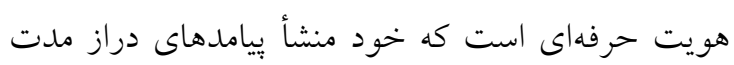

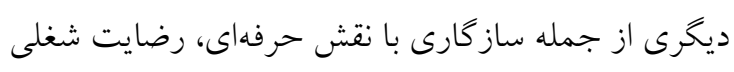

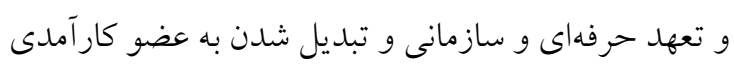

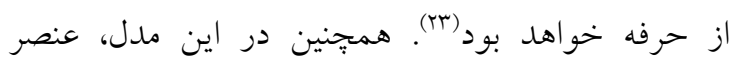

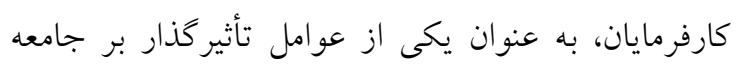

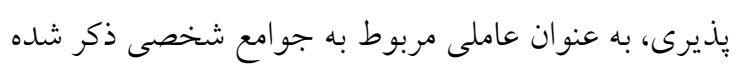
است. با توجه به اينكه اين مدل در رابطه با دانشجويان

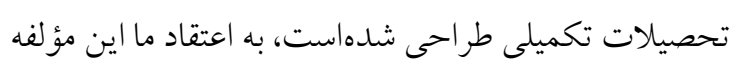

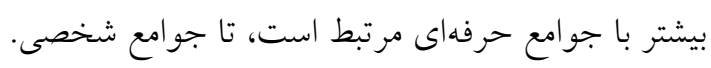

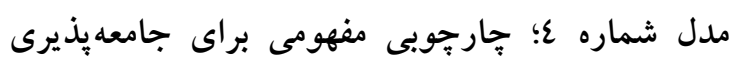

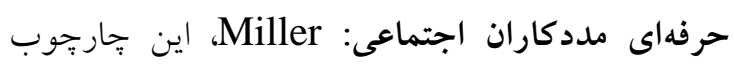

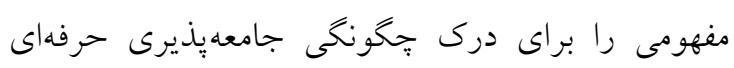

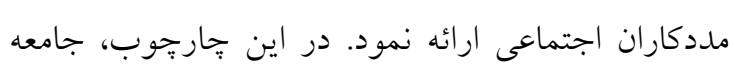

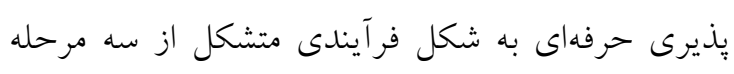

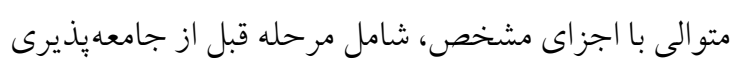

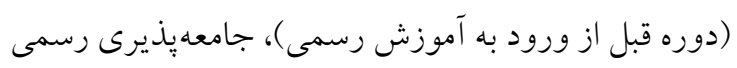

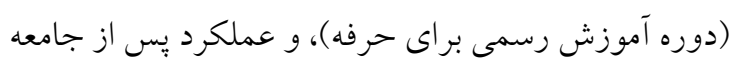

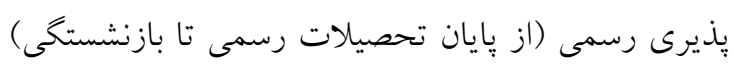

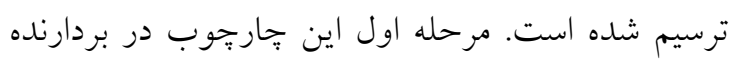

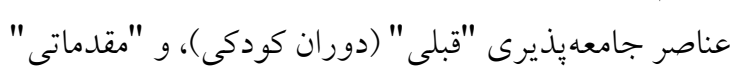

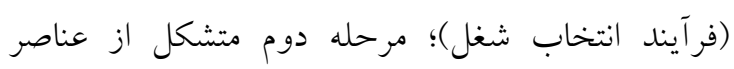

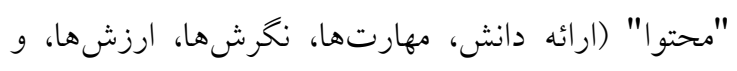


هويت حرفهاى، گرجهه به عنوان نقطه قوت اين مدل، مطرح

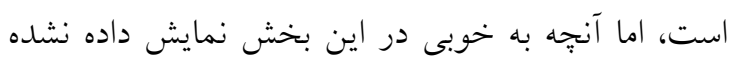

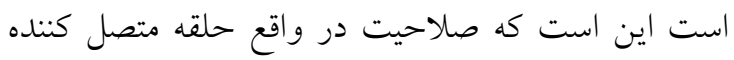
جزء روانى و اجتماعى هويت حرفهاى است. با كسب اسب

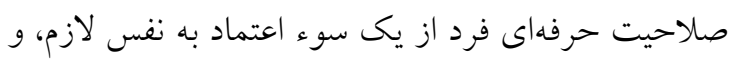

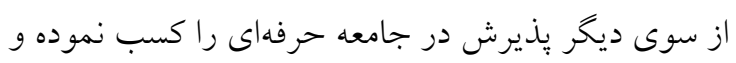

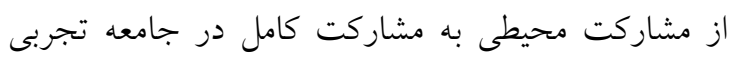
يادگيرى دست خواهد يافت. اما بايد توجه داشت كه

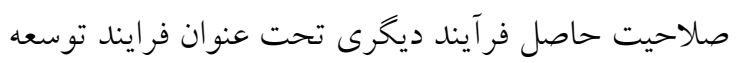
صلاحيت (Competency development process) است، كه يزدانى و همكاران، در مدلى جامع به (آن آن

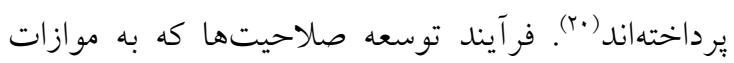

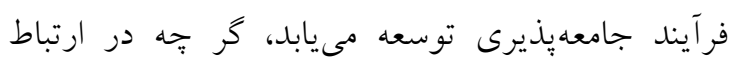

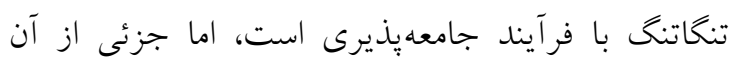

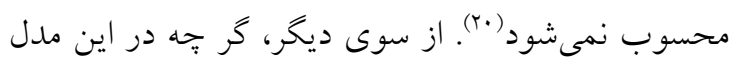

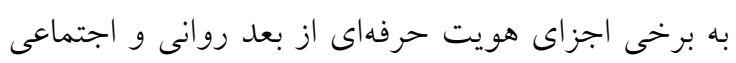

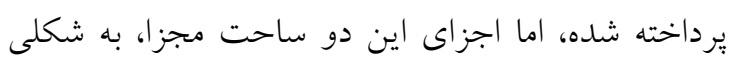
مستقل مورد بررسى و تصريح قرار نخرفتهاند. مدل شماره 7؛ تجربه تبديل شدن به يكى بيرايزشك:

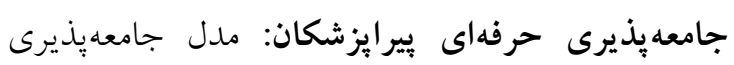

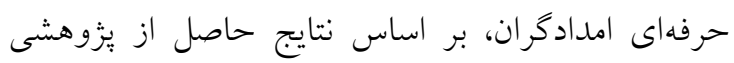

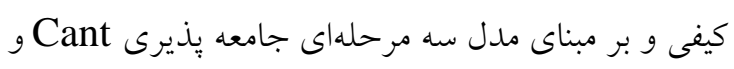
مiggs قياسى Charmaz تحليل اطلاعات استفاده شده است. اين مدل شامل جهار

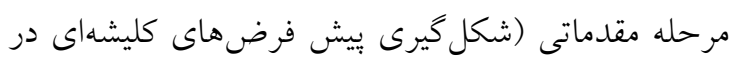

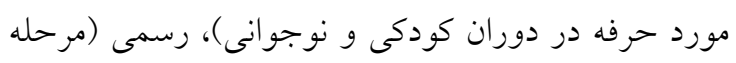

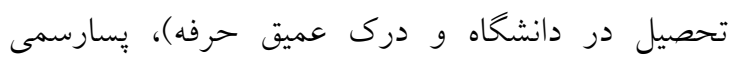

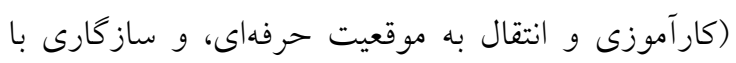

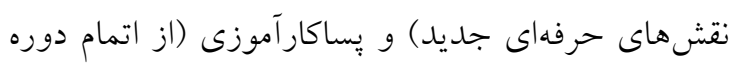

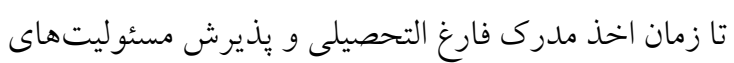

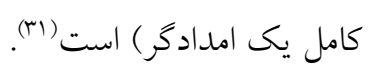

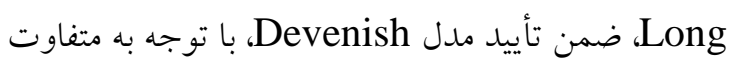

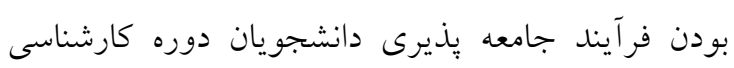

نشان مىدهد. تمركز بخش دوم مدل، بر تأثير تعامل با افراد

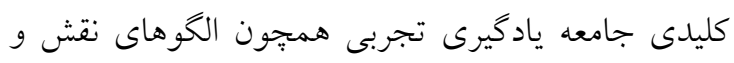

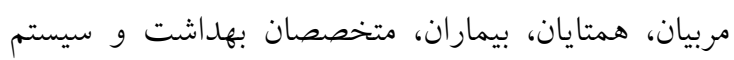

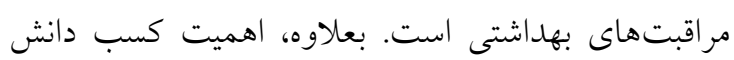
صريح و ضمنى، و يادكيرى تجربى از طريق فرأيندهاى

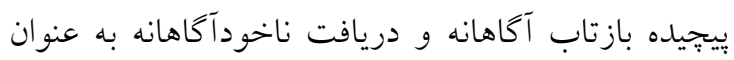

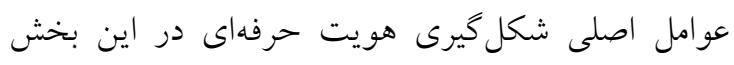

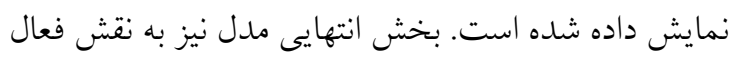

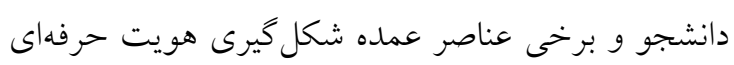

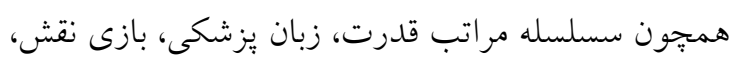

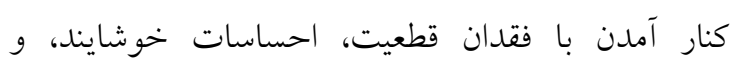
ناخوشايند و تطابق با هنجارها مى بردازد فئ. Silveira

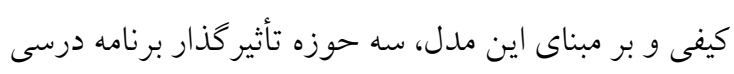

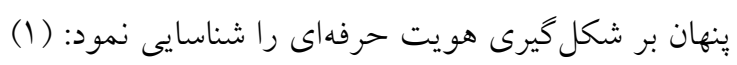

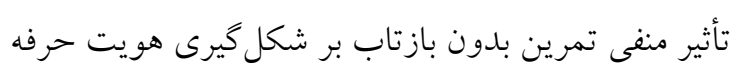

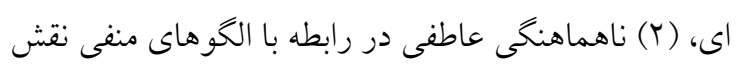

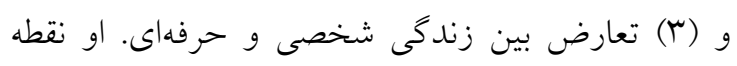

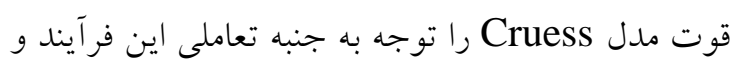
نقش تعامل در شكل كيرى هويت حرفهاى بيان مى كند (or).

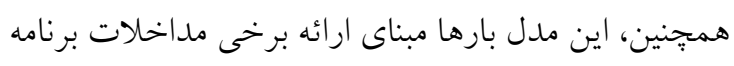

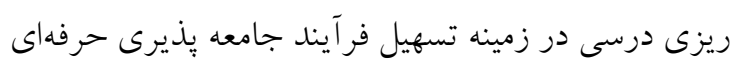

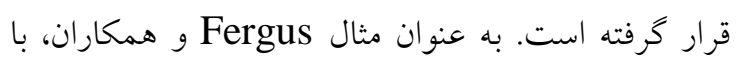

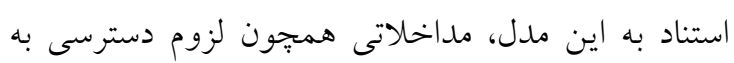

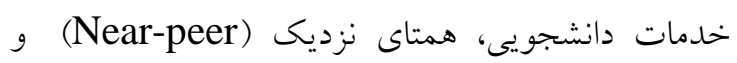

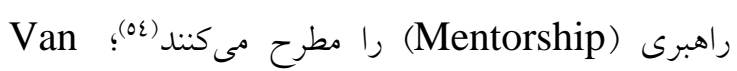
den Broek

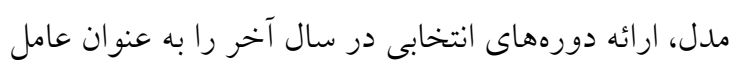

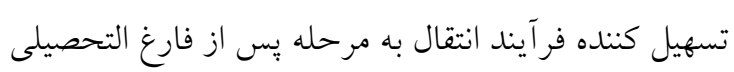

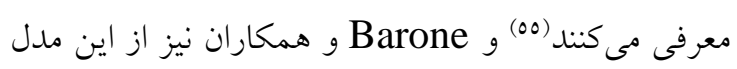
جهت ارائه راهبردهايى براى تسهيل شكل گئرى هويت حرفهاى در نسل هزاره استفاده نموده اند (07) بكائ.

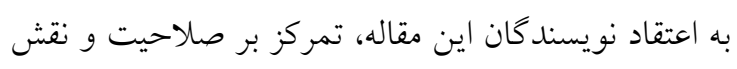

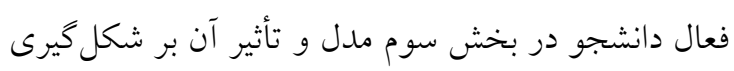




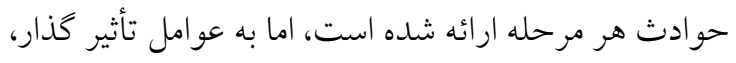
تسهيل كنندها و تصديع كنندهاى اين فرآيند نيز اشاره

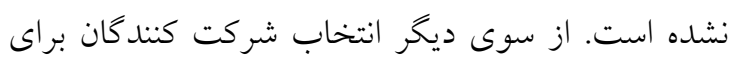

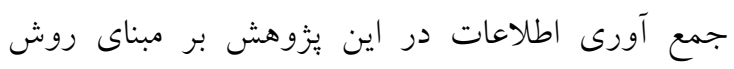

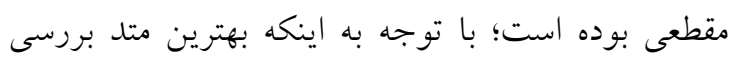

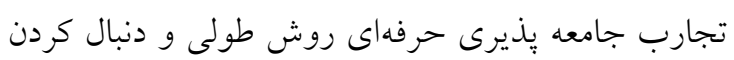

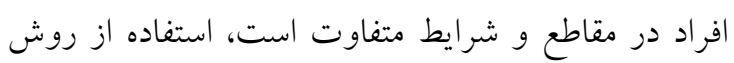

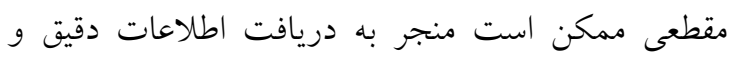
واقعى نخردد. مدل شماره V؛ الكوى مفهومى جامعهيذيرى حرفهاى در

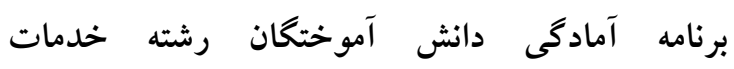
دانشجويى: Perez، اين مدل مفهومى را در رابطه با جامعه رانس پذيرى حرفهاى مقطع تحصيلات تكميلى رشته امور

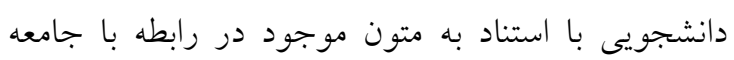

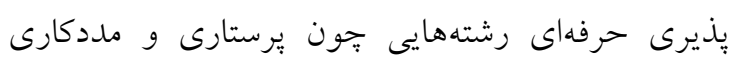

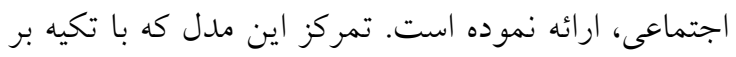

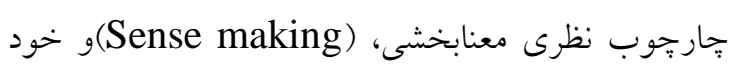

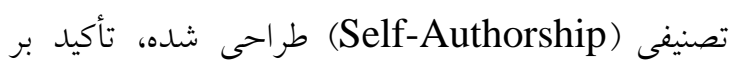
سازو كارهاى شناختى دخيل در اين فرآيند كه حاصل تعامل

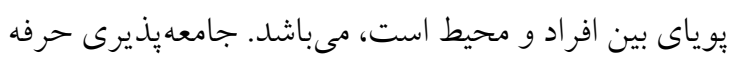

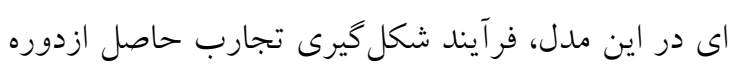

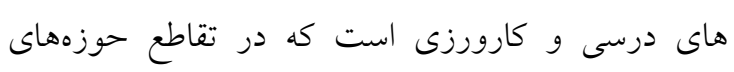

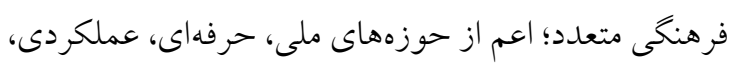

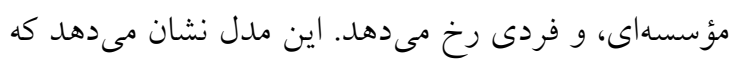

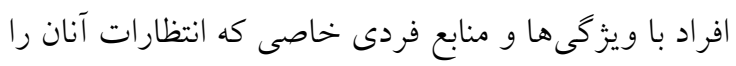

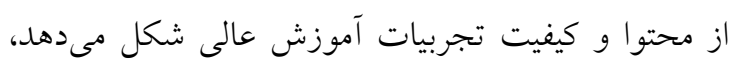

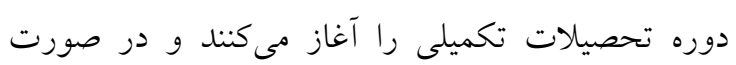

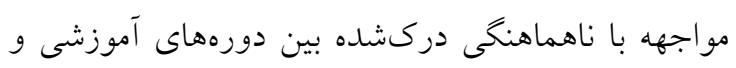

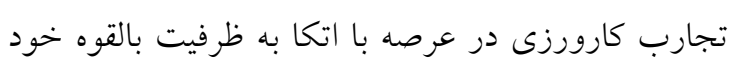
تصنيفى خود، از منابع مختلف معنا بخشى براى تفسير اين ناهماهنكى ها بهره مى گيرند (rr).

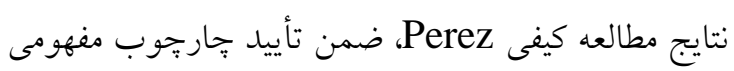

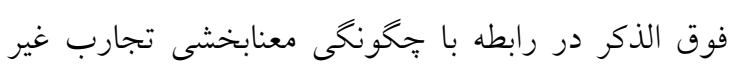

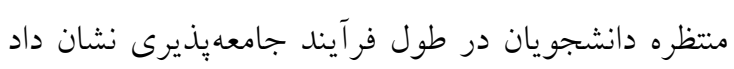

امدادكرى با فرايند انتقال امدادگران باتجربهاى كه قصد

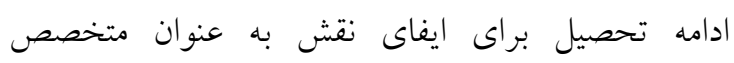

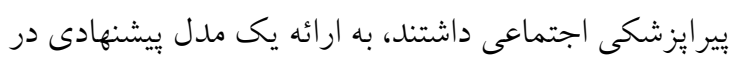

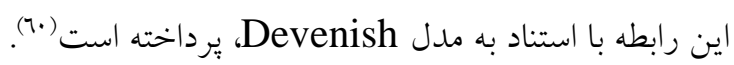

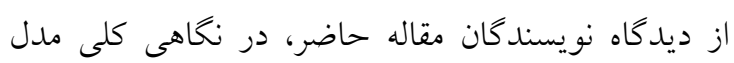
جهار مرحلهاى Devenish، نوعى مدل تكاملى مبتنى بر داه

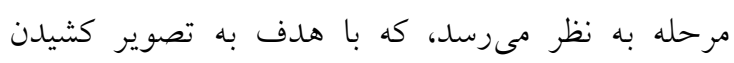

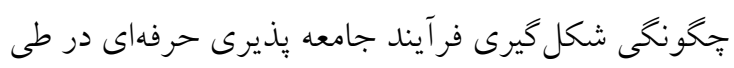

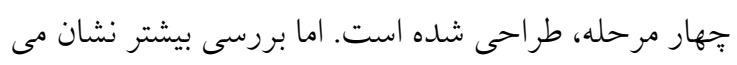

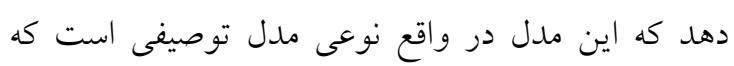

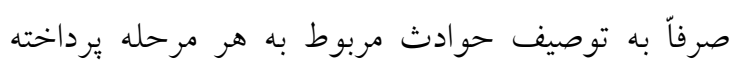

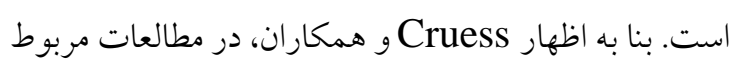

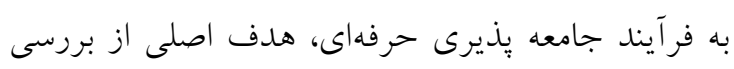

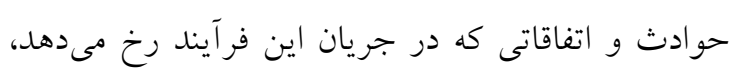

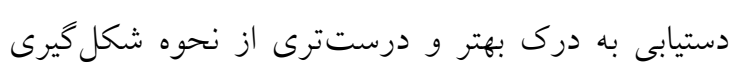

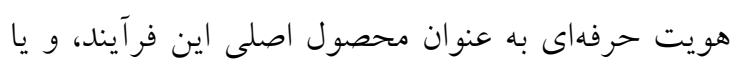

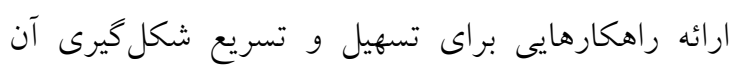

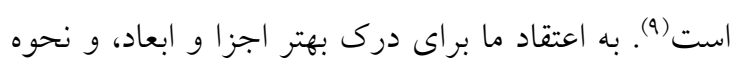

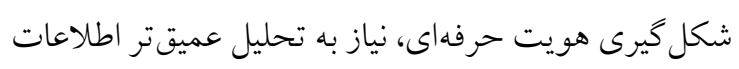

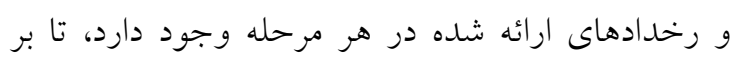

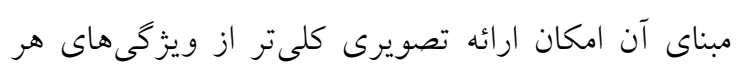

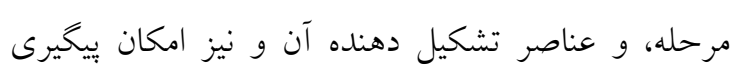
نحوه تحول اين اجزاء فراهم شود. بعلاوه در اين مدل ابعاد

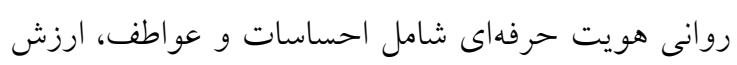

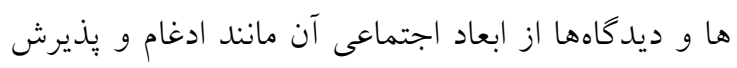

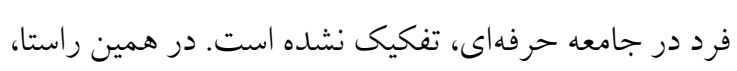
Domenici

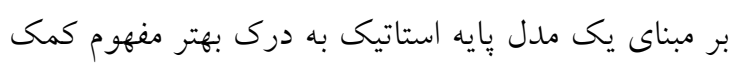

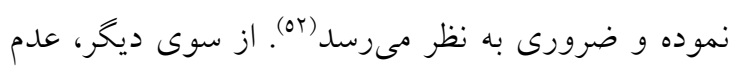

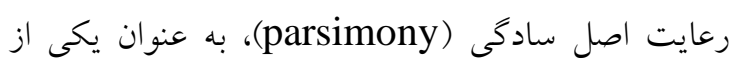

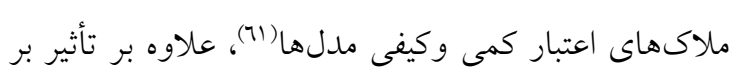

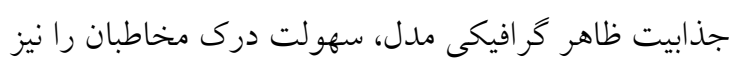
تحت تأثير قرار داده است. نكته ديكر اينكه، با وجود اينكه

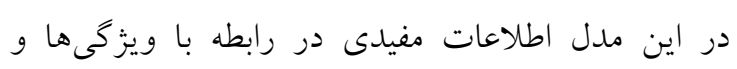


نيرداخته، و صرفاً بر مبناى ساز و كارهاى شناختى و روانى جامعهيذيرى بنا نهاده شده است.

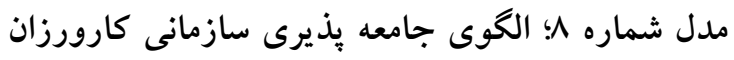
يزشكى در فرآيند انتقال به كارآموزى: Atherley و

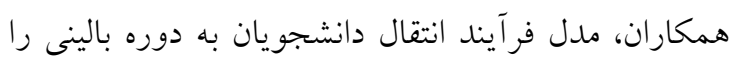

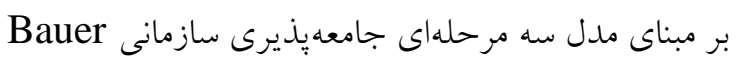
و بrdogan

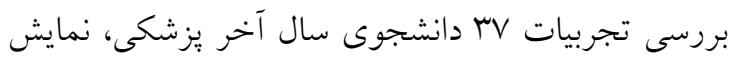

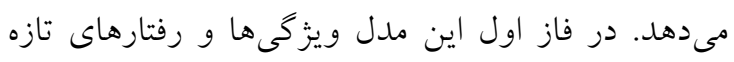

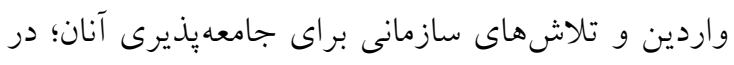

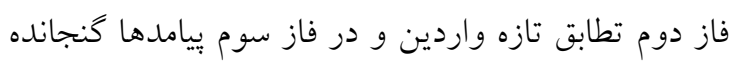

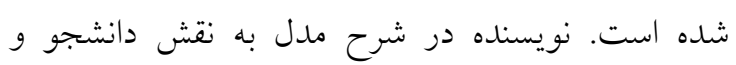

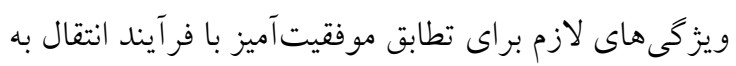

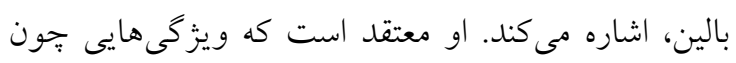

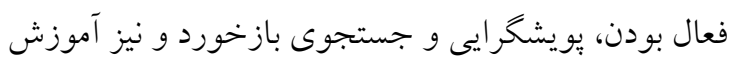

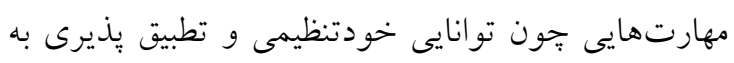

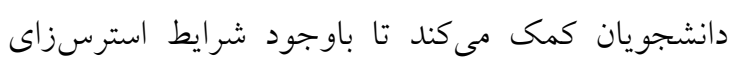

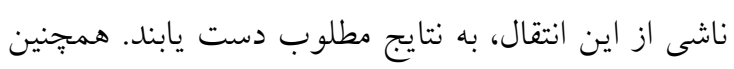

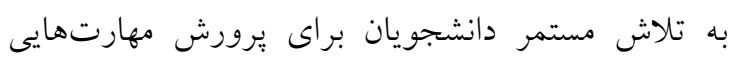

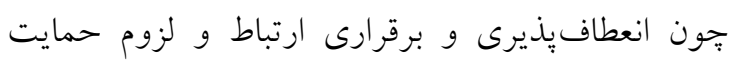
اعضاى تيم از دانشجويان در اين راستا اشاره مى كند.

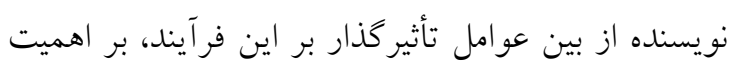

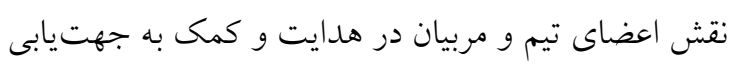

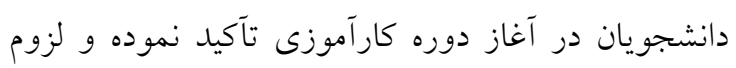

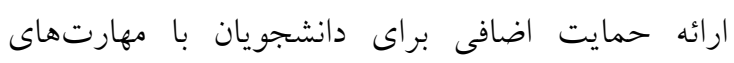
سازمانى و يادكيرى ضعيف را مطرح مىنمايد. در فاز دوم

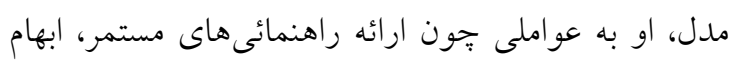

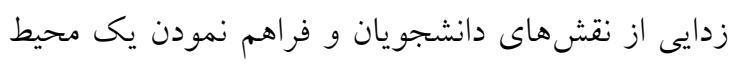
امن آموزشى براى حمايت از يادكيرى مؤثر دانشجويان

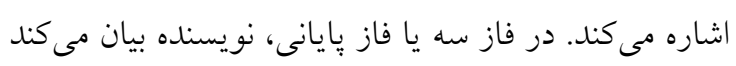

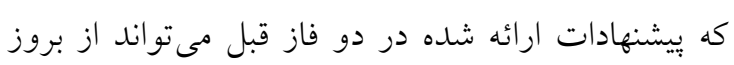
نتايج منفى اين فرآيند، هميجون اضطراب كه مىتواند تأثيرات نامطلوبى بر يادگيرى داشته باشد بيشخيرى نموده ينه
كه دانشجويان با وجود مواجهه با تجارب مشابه در اين فرآيند، بر اساس ظرفيت خود تصنيفى متفاوتى كه از آن

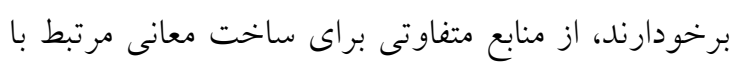

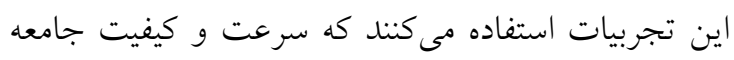
بذيرى آنان را در اين فرآيند رقم مىزند (باتهات

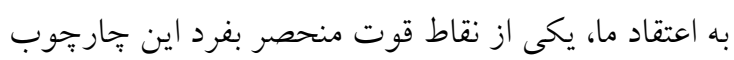

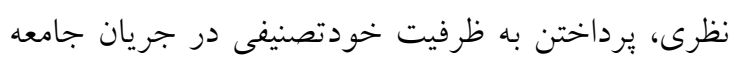

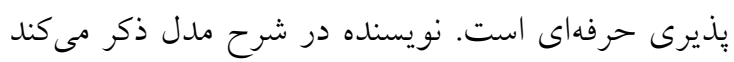

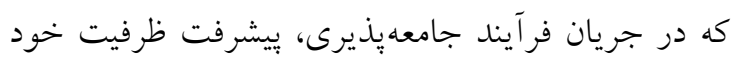

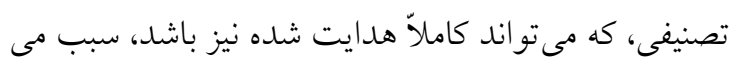

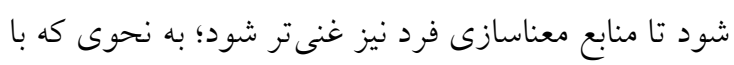

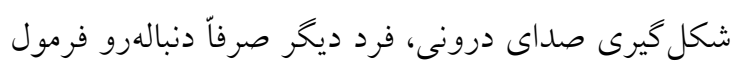

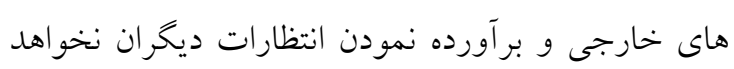

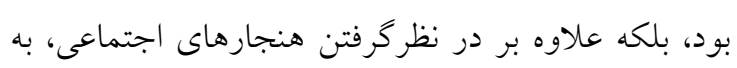

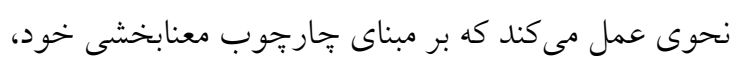

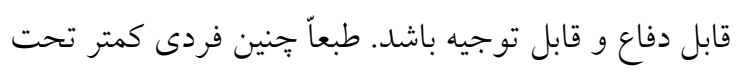
تآثير هنجارهاى نامطلوب و بعضاً غير اخلاقى محيط قرار

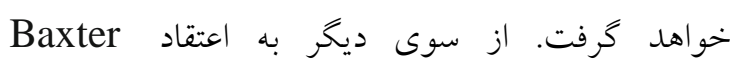
Magolda دانشخاه نيز بر كيفيت و سرعت فر آيند جامعهيذيرى تأثير

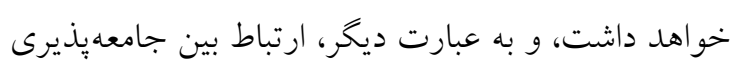
و خود تصنيفى ارتباطى دو طرفه و متقابل است (1ع). نكته

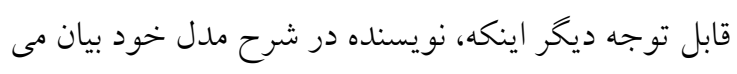

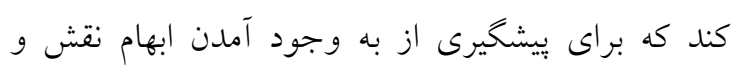

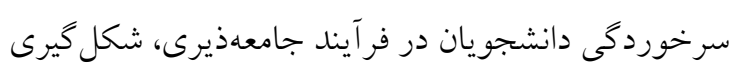

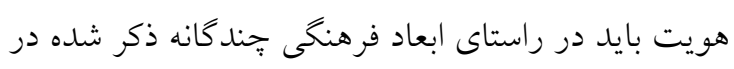

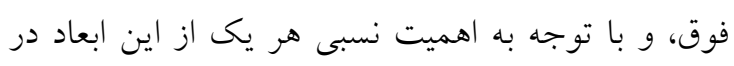

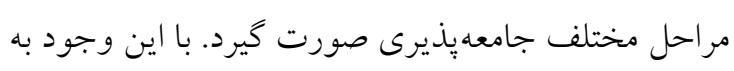
جز اشاره مختصرى به جنسيت و نزاد در شرح مدل، در مرئ

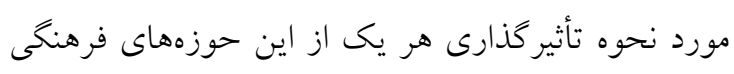

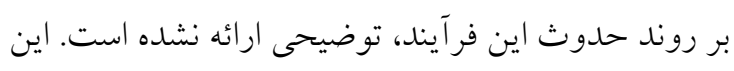

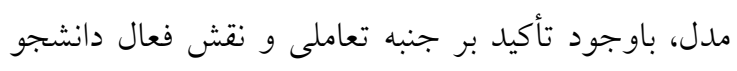
در فرآيند جامعهيذيرى حرفهاى، به جنبه هايى بيرونى و بعد

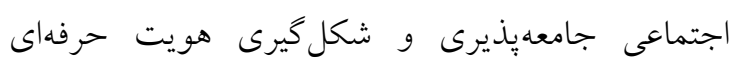


در فاز اول و تحت عنوان ويزگگىهاى تازه واردان آمده،

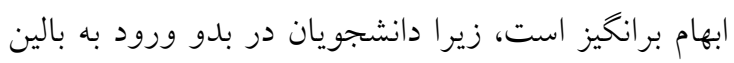
معمولاً فاقد تجارب خاصى در اين رابطه مىباشند. Atherley سازمانى، به عنوان مبناى اين يزّوهش را وروود دانشجويان

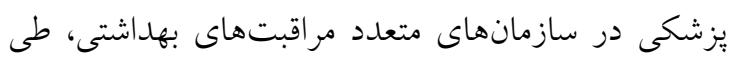

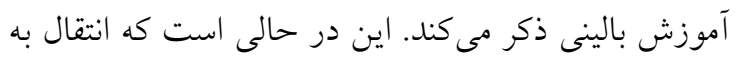

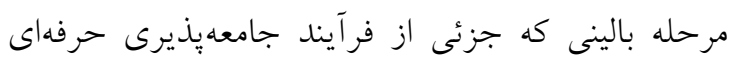

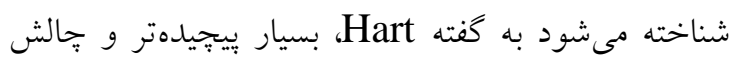
برانكيزتر از فر آيند جامعهديذيرى سازمانى است بـ (70). در تأييد

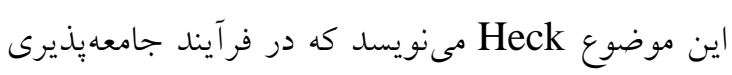

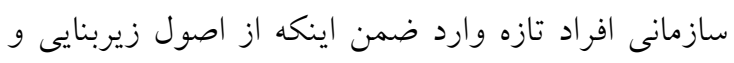

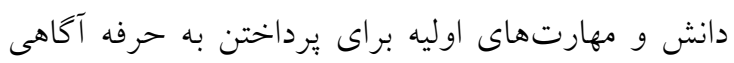

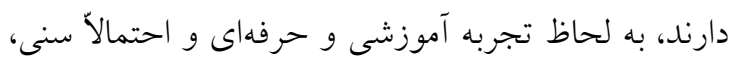
بسيار متفاوت از دانشجويان تازه وارد كم تجربه تهربه مىباشند (17). در مجموع اين مدل باوجود كاستىهاى دان ساختارى، در بر دارنده راهكارهاى مفيدى براى تسهيل فرآيند انتقال مىباشد. مدل شماره 9؛ حرفهاى شدن دانشجويان بزشكى باندا: Byram در اين مدل بر مبناى مطالعهاى كيفى با رويكرد

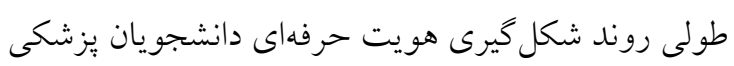

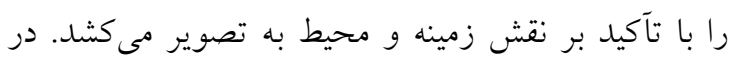
اين مطالعه، روند شكل گيرى هويت حرفهاى در طول سال

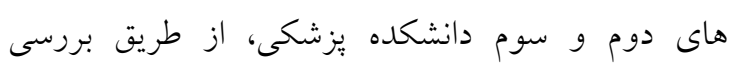

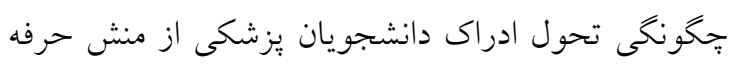

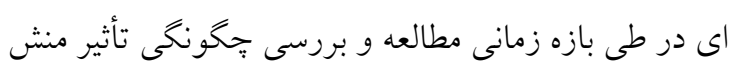

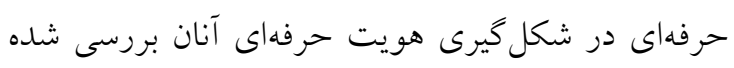

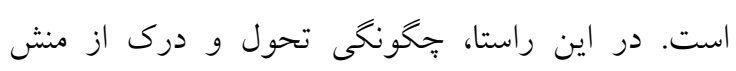

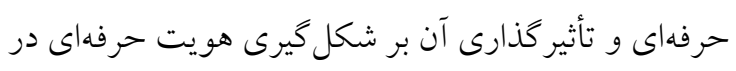

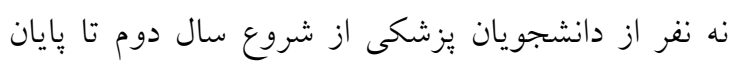

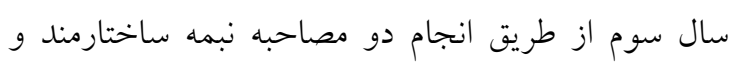

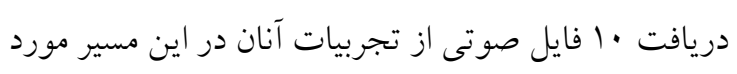
بررسى و تجزيه و تحليل قرار كرفت. بر اساس نتايج، ينج

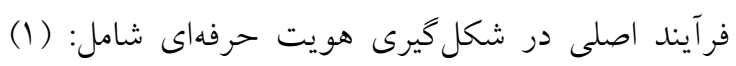

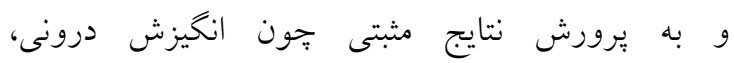

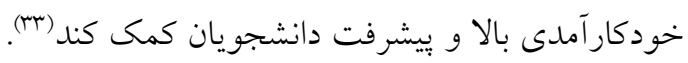

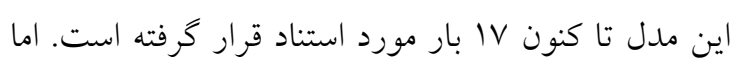

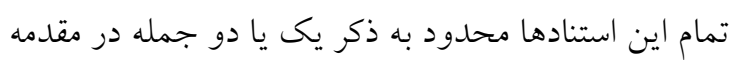

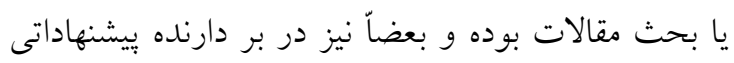

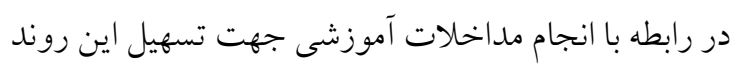

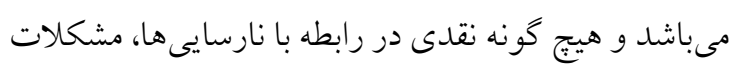
و يا كمبودهاى احتمالى اين مدل، يا بيشنهادى براى ارتقاء

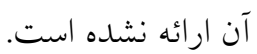
مطالعه شرح مدل نشان مىدهد كه هدف محقق، طراحى نـ انده

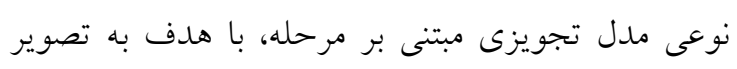

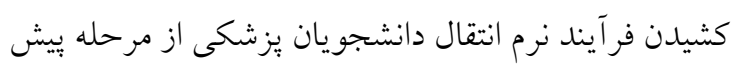

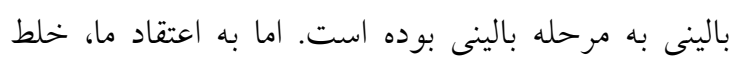

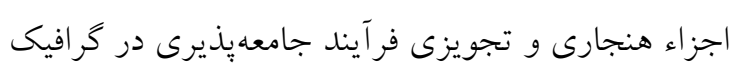

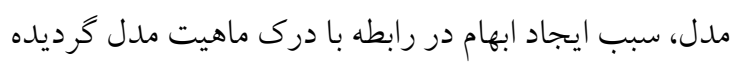

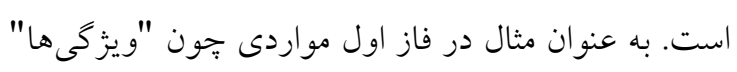

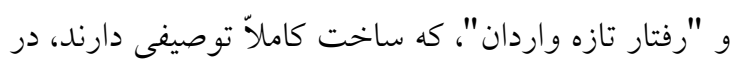

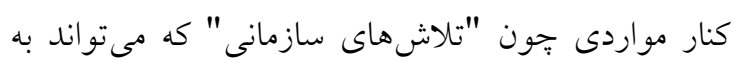
تسريع و تسهيل فرآيند جامعه يذيرى كمى كند، و داراى

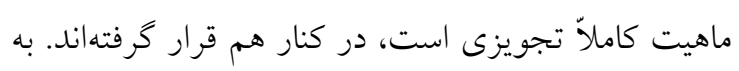

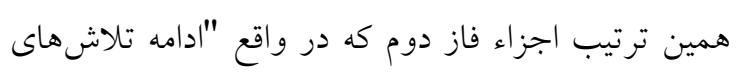
سازمانى فاز يك" است نيز تجويزى بوده، در حالى كه

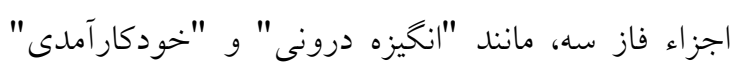
جزء ويزگى هاى فردى بوده و بنابراين توصيفى محسوب انداء

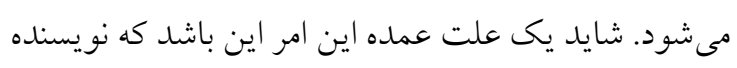

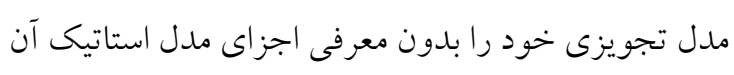

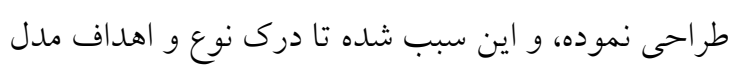
براى مخاطب دشوار و ابهامانخيز باشد.

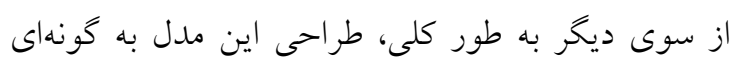

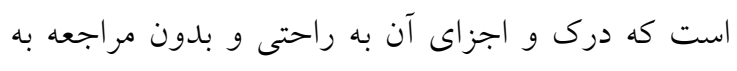

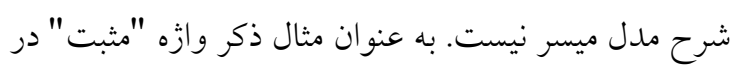
خصوصيات دانشجويان تازموارد در مرحله اول، ابهامزا بوده، و نمىتواند منظور دقيق محقق را به مخاطب منتقل

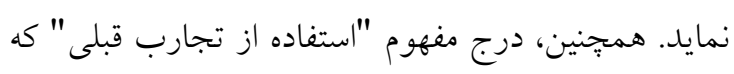




\section{نتيجه گيرى مرور نقادانه}

در اين يزوهش، مدلها و جهارجوب ههاى مفهومى منتخب در زمينه جامعهيذيرى و شكلگيرى هويت حرفهاى (جدول شماره ()، مورد بررسى قرار گرفت. مدلهاى مورد بررسى را مىتوان به جهار دسته شامل مدلهاى صرفاّ

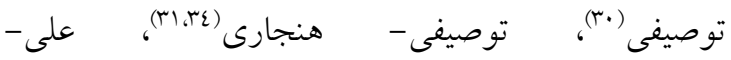

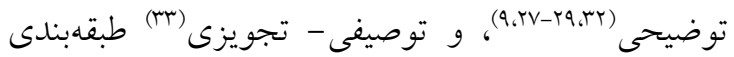
نمود. بيشتر اين مدلها صرفاً به ارائه توصيف بخشهايى لجريى

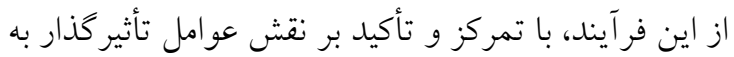

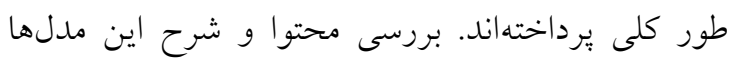

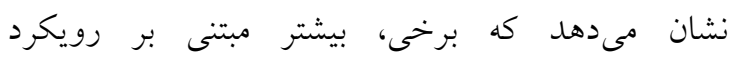

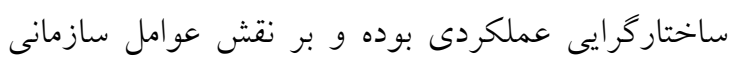

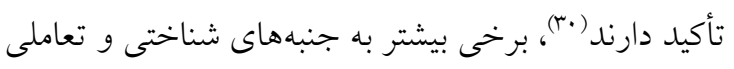

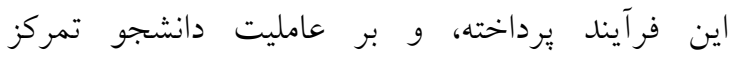

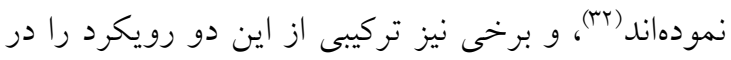
بردارند، و علاوه بر نقش عوامل محيطى و مؤسسهاى به

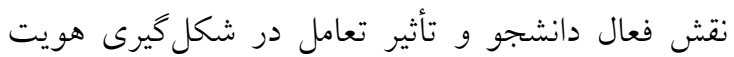

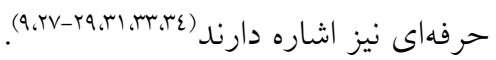

اتصال به تصوير بزشكى، (Y) كاوش خود در بزشكى، (r) تجسم نقش در يزشكى، (ع) كاوش در انتخاب تخصص و و

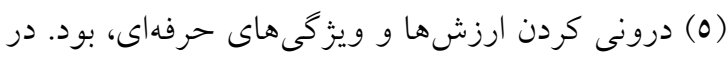

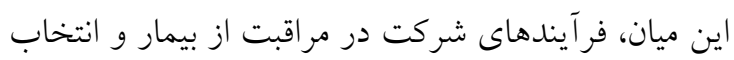

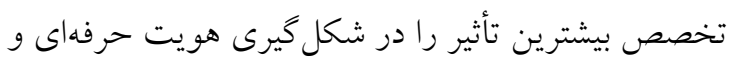
ايجاد حس تعلق به جامعه حرفهاى نشان داد (عَ).

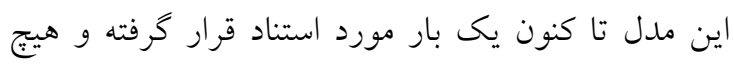

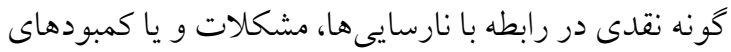
احتمالى اين مدل يا ييشنهادى براى ارتقاء آن يافت نشد. نكته مهم در اين مدل، توجه به ابعاد روانى (درونى كردن ارزشها و ويزگى هاى حرفه، كاوش خود در يزشكى، اتصال به تصوير يزشكى، كاوش در انتخاب تخصص) و اجتماعى (تجسم نقش در يزشكى) هويت حرفهاى است.

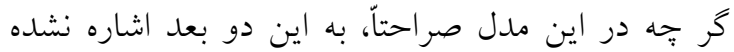

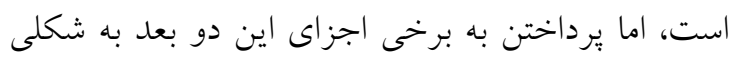

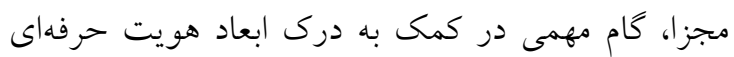

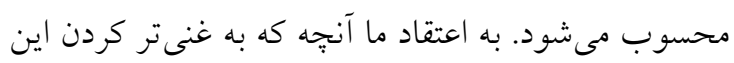

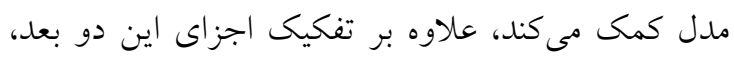

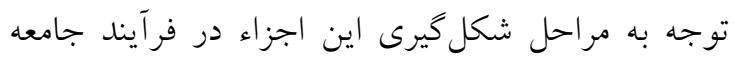

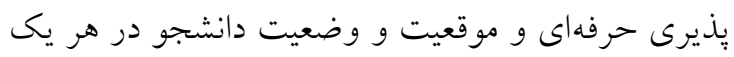

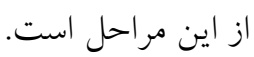

جدول شماره (: طبقه بندى مدلهاى جامعهيذيرى، و شكل

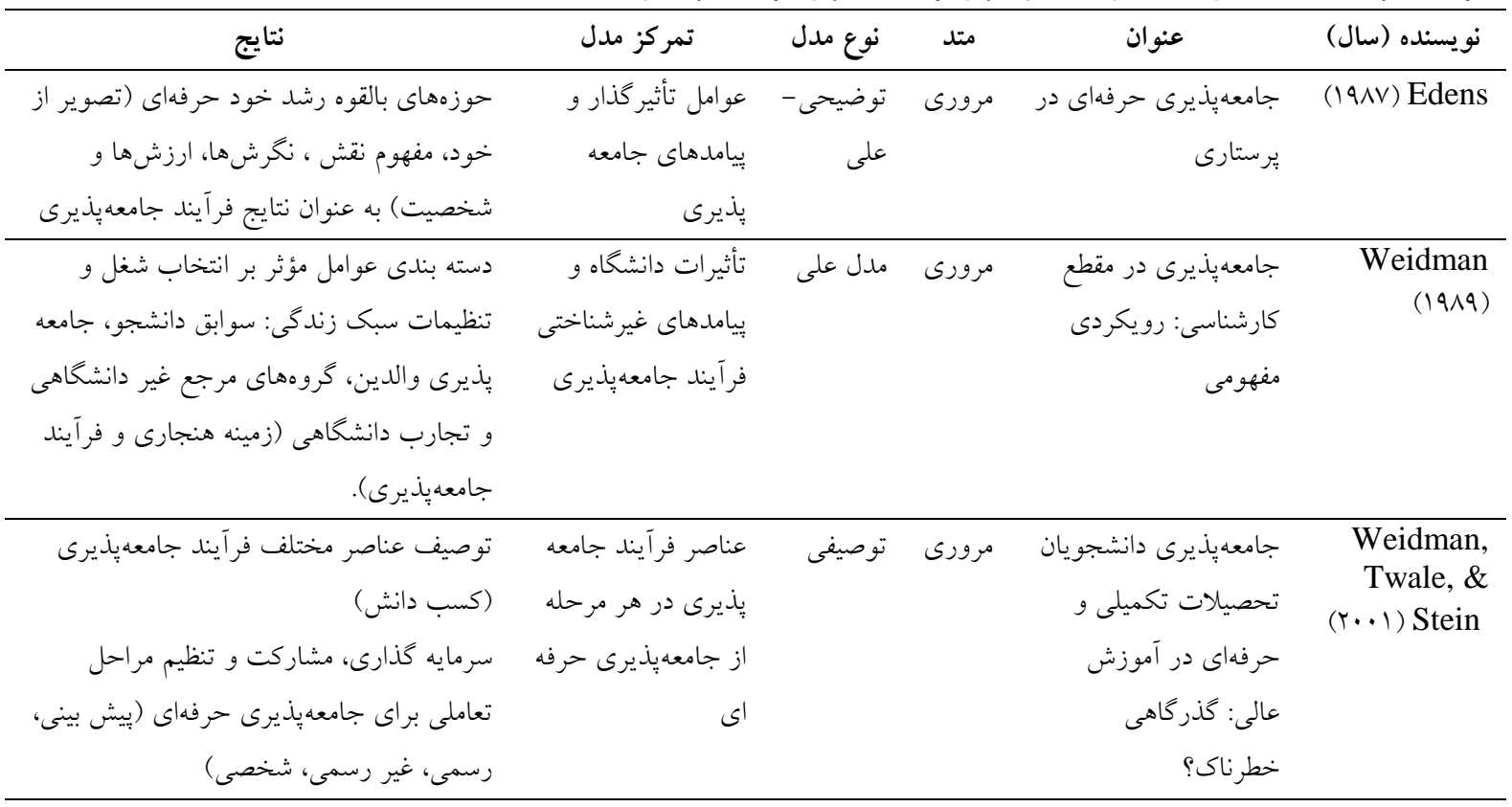




\begin{tabular}{|c|c|c|c|c|c|}
\hline 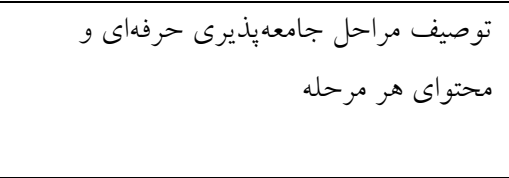 & 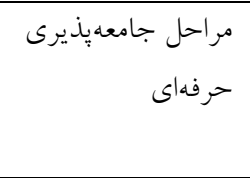 & توصيفى & مرورى & 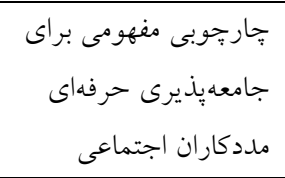 & $\begin{array}{l}\text { Miller } \\
(\uparrow \cdot 1 \cdot)\end{array}$ \\
\hline 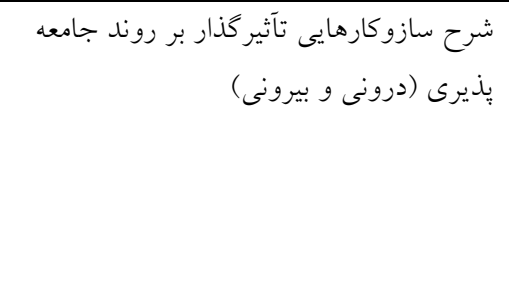 & 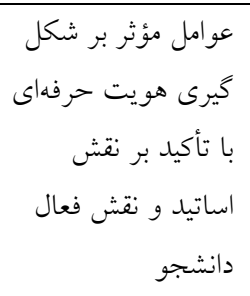 & توضيحى - & مرورى & 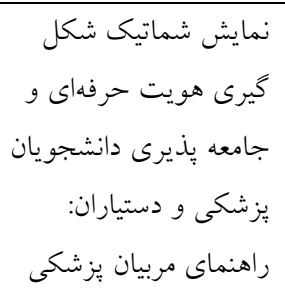 & 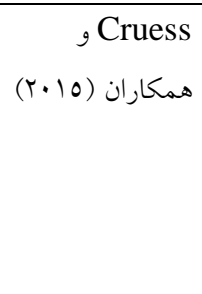 \\
\hline تعرح وقايع و و ويزّله براى جامعه يذيرى حرفهاى و & 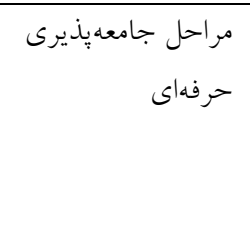 & هنجارى & كيفى & 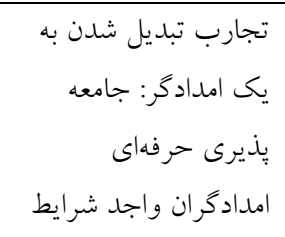 & $\begin{array}{r}\text { Devenish, } \\
\text { Clark, \& } \\
\text { Fleming } \\
(\uparrow \cdot 17)\end{array}$ \\
\hline خوتبين تعامل يويا بين افراد و محيط در روند & 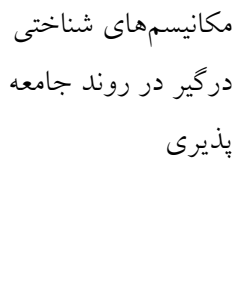 & توضيحى & مرورى & 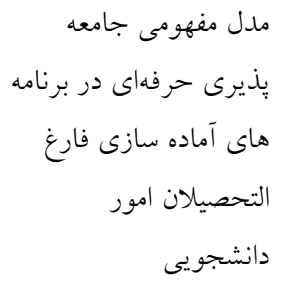 & $(Y \cdot 17)$ Perez \\
\hline توصيف عوامل مؤثر در اين روند و ارائه & آموزش آنت بال بالينى & تو تجويزى - ت & كيفى & 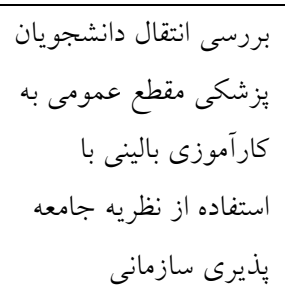 & $\begin{array}{r}\text { Atherley, } \\
\text { Hambleton\& } \\
\text { Unwin } \\
(r \cdot 17)\end{array}$ \\
\hline 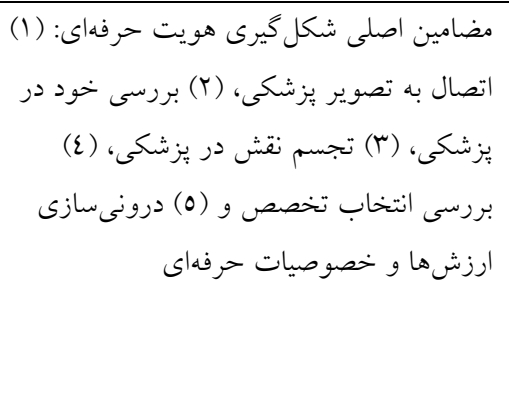 & 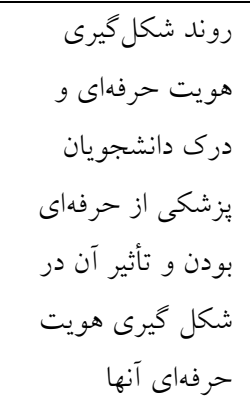 & توصيفى - & كيفى & 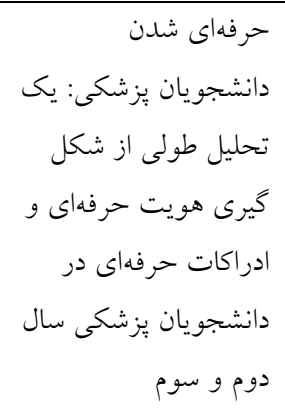 & $\begin{array}{r}\text { Byram } \\
(Y \cdot I V)\end{array}$ \\
\hline
\end{tabular}

سبك زندكى آينده دانشجويان صر احتاً مورد انكار، و نقش

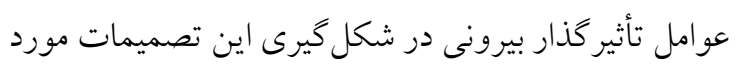

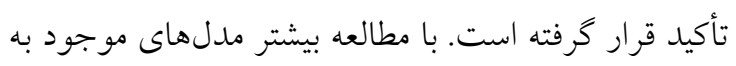

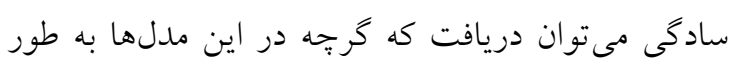

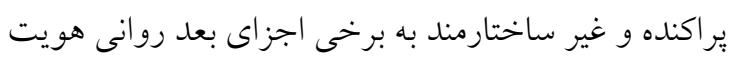

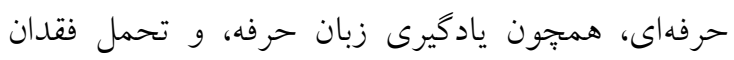

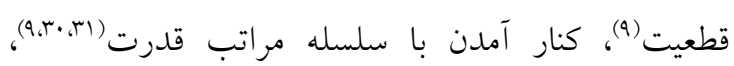

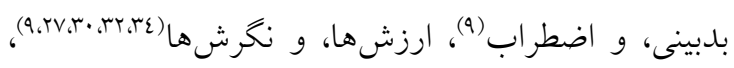

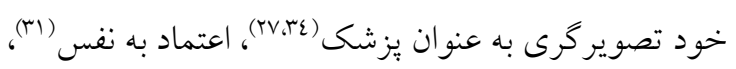

بررسى و تحليل اين مدلها نشان مىدهد، كه هر يك از

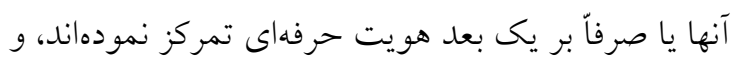

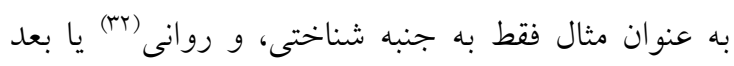

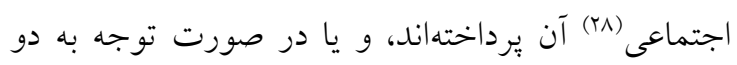

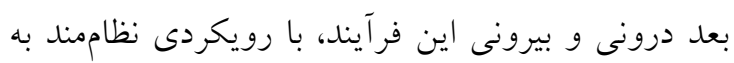

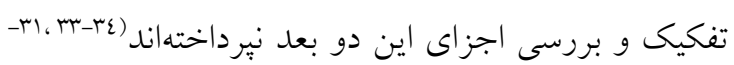
(9.rV،rq

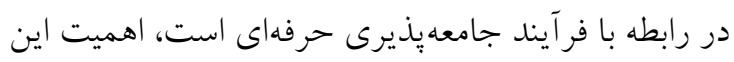

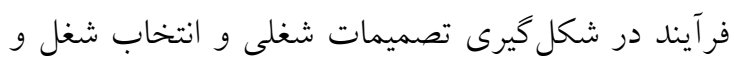


بييجيده و مفاهيم انتزاعى كمتر شناخته شده است، تا علاوه بر كمك به توليد، انتشار و يذيرش يافتههاى علمى، امكان اعمال ادر اكات علمى در واقعيت، و ارائه مداخلات هدفمند درآن مسير را فراهم نمايند. كرجه نتايج مطالعات موجود در اين زمينه كمك زيادى به روشن شدن زواياى تاريك اين فرآيند، و عوامل تأثير گذار

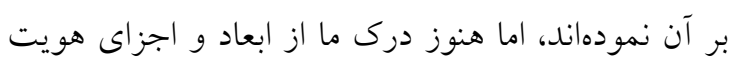
حرفهاى به عنوان بيامد مطلوب و مورد انتظار جامعهيذيرى

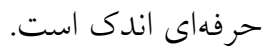
بنابراين در اين مطالعه تلاش شد تا با بررسى دقيق مفاهيم كليدى جامعهيذيرى و هويت حرفهاى استخراج شده از مدلهاى مورد بررسى (جدول شماره Y)، و مرور دقيق متون به شناسايى ابعاد هويت حرفهاى و مؤلفههاى آنها يرداخته شود، تا از اين طريق امكان رصد كردن اين مؤلفه ها در طى فرآيند جامعهيذيرى حرفهاى و به تبع آن امكان ارائه مداخلات هدفمند، جهت مديريت صحيح اين فرآيند در مطالعات آتى فراهم كردد.

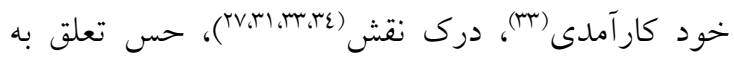
حرفه(ع)، انتخاب تخصص، و شغل آينده(ع)، نيز برخى اجزاى بعد اجتماعى هويت حرفهاى مانند تعامل و و

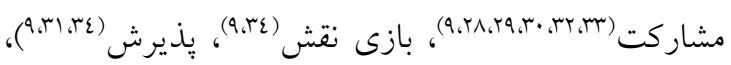

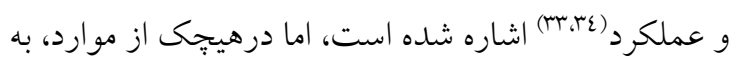
ابعاد هويت حرفهاى و نيز سازهها و زير سازههاى آن در قالب يك مدل ساختارى زيربنايى :رداخته نشده است. از سوى ديخر، رعايت نكردن اصل سادكى (parsimony)،

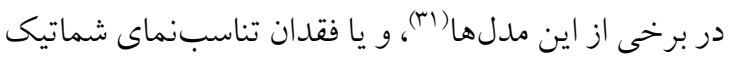
مدلها كه در ظاهر تكاملى و جنه مرحلهاى مىنمايد، حال آنكه شرح مدل حكايت از ماهيت صرفاّ توصيفى آن

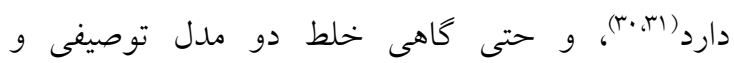
تجويزى(Tr(T)، سبب شده كه برخى از اين مدلها، با وجود ارائه اطلاعاتى مفيد در اين زمينه، به درك عميق اين فرآيند، و امكان بيخيرى نحوه تحول ابعاد و اجزاى آن كمى ننموده، و حتى گاهى منجر به سردرگمى مخاطب نيز كردند؛ حال آنكه يكى از مهمترين اهداف طراحى مدلها، ارائه توضيحات علمى، از طريق ترسيم ساده بديدههاى

جدول شماره ז: مفاهيم كليدى جامعهيذيرى و هويت حرفهاى مدلهاى مورد بررسى (1901)

Edens G.(1987)

Values, Attitude, Self-image, Role conception

Miller S. E., (2010)

Values, Attitudes, Culture, Interpersonal, Relationship, Power structure, Engagement

Weidman J.C. (1989)
Values, Intrapersonal process, Career choice, Integration, Interaction

Cruess R. et al (2015)

Learning to live with ambiguity, Learning the hierarchy \& power relationships, Learning the Symbols \& rituals, Unconscious reflection, Selfassessment, Increased competence, Socialization negotiation, Detached concern, Loss of innocence, Language, Cynicism, Marginalization, Social interaction, Participation,

Clinical/nonclinical experiences

\begin{tabular}{lll}
\multicolumn{1}{c}{ Perez R.J. (2016) } & Clinical/nonclinical experiences & \multicolumn{1}{c}{ Byram J.N.,(2017) } \\
\hline Values, Meaning making, Role & Self-efficacy, Internal motivation, & Envisioning self as a member of Specialties, \\
expectation, Assumption about & Role clarity & Reexamine commitment, Reaffirm \\
profession, Capacity for self- & & $\begin{array}{l}\text { commitment, Professional values, Evaluate } \\
\text { self in future specialty, Doubting about } \\
\text { place in medicine,Individual fit with } \\
\text { authorship }\end{array}$ \\
& & $\begin{array}{l}\text { specialty,Selecting specialty } \\
\end{array}$
\end{tabular}

\section{Weidman J.C. et al, (2001)}

Institutional culture, Peer climate Integration, Interaction, Involvement, Investment, Commitment

\section{Devenish A. et al, (2016)}

Adjusting to the culture, Biculturalism, Building confidence, Stereotypical role image, Understanding of the role, Choosing an employer, Helping people,

Marginalization, Gaining Acceptance, Increased level of acceptance, Focusing on skills specialty,Selecting specialty
اين فرآيند كه در حقيقت فرآيند مشروعيت بخشيدن به

اقتدار حرفهاى فرد در اجتماع است، از طريق تحول
بر اين اساس هويت حرفهاى را مى توان سازهاى متشكل

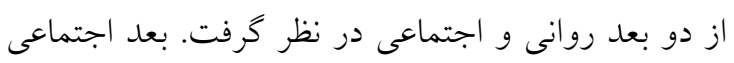




$$
\begin{aligned}
& \text { و نيز مدل تكاملى آن جهت بيخيرى نحوه توسعه هر يك } \\
& \text { نمادين، فكرى و روانى فرد در اين مسير حاصل }
\end{aligned}
$$

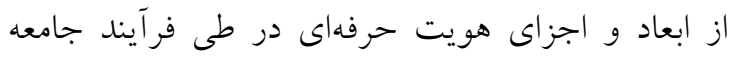

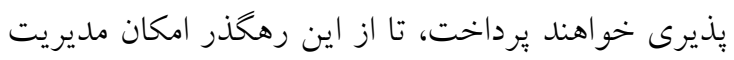

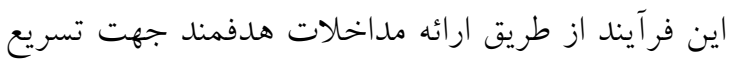

$$
\begin{aligned}
& \text { و تسهيل شكل گيرى مطلوب هويت حرفهاى فراهم گردد. } \\
& \text { تعارض منافع: نويسندكان هيج كونه تعارض منافعى را }
\end{aligned}
$$

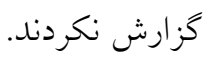

$$
\begin{aligned}
& \text { تقدير و تشكر }
\end{aligned}
$$

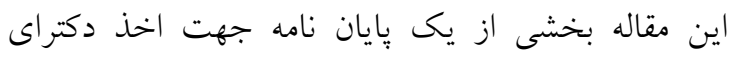

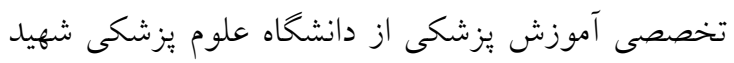

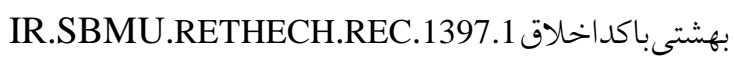

$$
\begin{aligned}
& \text { است. بدين وسيله از همكارى مسؤولين بزووهشى دانشگاه } \\
& \text { قدردانى مى گردد. }
\end{aligned}
$$

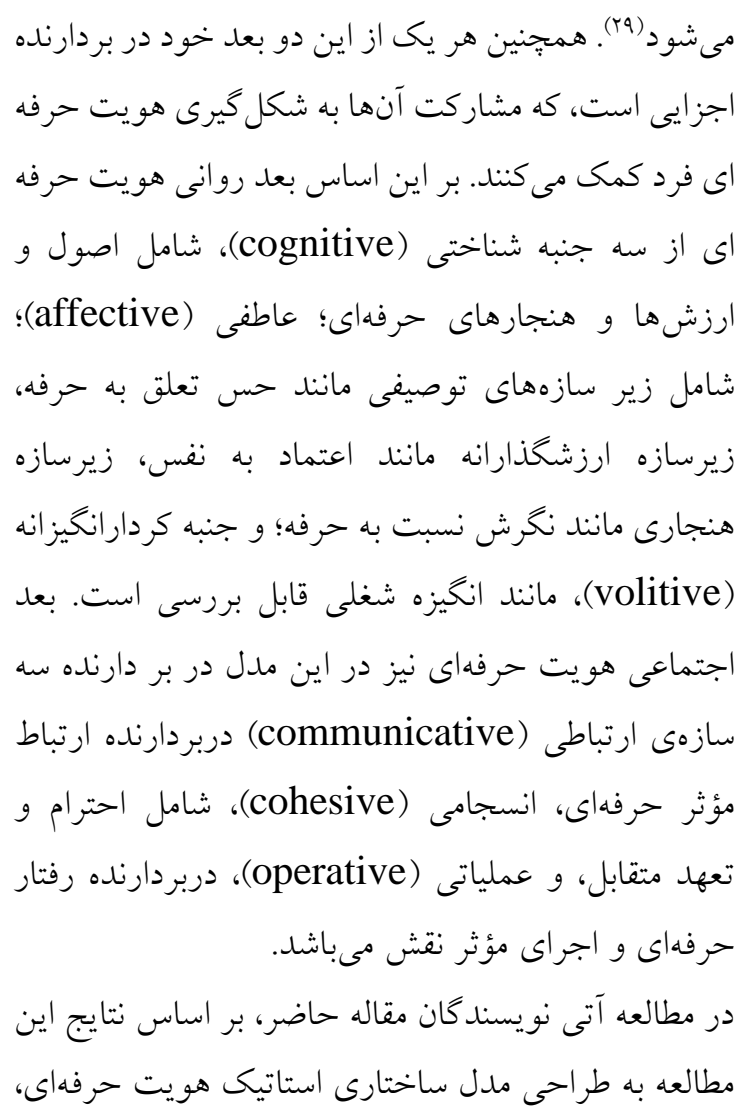

\section{References}

1. Spiwak R, Mullins M, Isaak C, Barakat S, Chateau D, Sareen JS. Medical students' and postgraduate residents' observations of professionalism. Educ Health. 2014;27(2):193-9.

2. Cruess SR \& Cruess RL. Professionalism and medicine's social contract with society. V.M. 2004; 6(4): $185-88$.

3. Mughal Z, Mughal F. The junior doctor contract in the National Health Service. J Fam Med Prim Care. 2016;5(2):225-7.

4. Becker GJ. Understanding and applying the principles of contemporary medical professionalism: illustration of a suggested approach, part 2. J Am Coll Radiol. 2015;12(1):12-4.

5. Afshar L. Medical Oath: The Educational Impact. Med. Educ. 2016; 15(1): 1-13.

6. Razzaghi MR, Afshar L. A conceptual model of physician-patient relationships: a qualitative study. J Med Ethic Hist Medic. 2016;9(14):1-7.

7. Cruess SR, Cruess RL. Professionalism must be taught. Bmj. 1997;315(7123):1674-7.

8. Sivalingam N, Mal M. Teaching and learning of professionalism in medical schools. Ann Acad Med Singapore. 2004;33(6):706-10.

9. Cruess RL, Cruess SR, Boudreau JD, Snell L, Steinert Y. A schematic representation of the professional identity formation and socialization of medical students and residents: a guide for medical educators. Acad Med. 2015;90(6):718-25.

10. Seifrabei MA, Esna Ashari M, Maghsoodi F, Esna Ashari F. The Effect of Early Clinical Exposure Program on Attitude Change of Undergraduate Medical Students toward their preparation for Attending Clinical Setting in Internal Medicine, Surgery and Pediatrics Wards during 2013-2014. Avicenna Journal of Clinical Medicine. 2016;22(4):323-30. [Persian]

11. Yazdani S, Momeni S, Afshar L, Abdolmaleki M. A comprehensive model of hidden curriculum management in medical education. J Adv Med Educ Profess. 2019;7(3):123-30. 
12. Afshar L. Faculty Development; Prerequisite for Medical Student's Professional Formation. Afzalipour Journal of Clinical Research. 2017;2(3-4)):124-9. [Persian]

13. Yazdani S, Lake MA, Ahmady S, Forootan A, Afshar L. Critical interpretive synthesis of the concept of value in medical education. Research and Development in Medical Education. 2014;4(1):31-4. [Persian]

14. Beagan BL. "Even if I don't know what I'm doing I can make it look like I know what I'm doing": becoming a doctor in the 1990s. Canadian Review of Sociology/Revue canadienne de sociologie. 2001;38(3):275-92.

15. Cooke M, Irby DM, O'Brien BC. Educating physicians: a call for reform of medical school and residency. John Wiley \& Sons; 2010 Jun 1.

16. Cruess RL, Cruess SR, Boudreau JD, Snell L, Steinert Y. Reframing medical education to support professional identity formation. Academic Medicine. 2014;89(11):1446-51.

17. Bebeau MJ. Evidence based character development. In: Kenny NP, Shelton WN, eds. Lost Virtue: Professional Character Development in Medical Education. Oxford, England: Elsevier; 2006.

18. Jones EA, Voorhees RA. Defining and Assessing Learning: Exploring Competency-Based Initiatives. Report of the National Postsecondary Education Cooperative Working Group on Competency-Based Initiatives in Postsecondary Education. Brochure [and] Report. 2002.

19. Blais K, Hayes J, Kozier B, Erb G. Socialization to professional nursing roles. Upper Saddle River, NJ: Prentice Hall; 2002.

20. Yazdani S, Akbari-Farmad S. Providing the Meta-Model of Development of Competency Using the Meta-Ethnography Approach: Part 1: Reviewing the Available Models of Competency Development. Journal of Medical Education. 2016;15(2):65-74. [Persian]

21. Van Melle E, Frank JR, Holmboe ES, Dagnone D, Stockley D, Sherbino J, International Competency-based Medical Education Collaborators. A core components framework for evaluating implementation of competency-based medical education programs. Acad Med. 2019;94(7):1002-9.

22. Cruess RL, Cruess SR, Steinert Y. Amending Miller's pyramid to include professional identity formation. Acad Med. 2016;91(2):180-5.

23. Shahr HS, Yazdani S, Afshar L. Professional socialization: an analytical definition. J Med Ethics History Med. 2019;12(17): 1-14.

24. Grant MJ, Booth A. A typology of reviews: an analysis of 14 review types and associated methodologies. Health Infor libr J. 2009;26(2):91-108.

25. Carnwell R, Daly W. Strategies for the construction of a critical review of the literature. Nurse Educ Pract. 2001;1(2):57-63.

26. Atkins S, Lewin S, Smith H, Engel M, Fretheim A, Volmink J. Conducting a meta-ethnography of qualitative literature: lessons learnt. BMC Med Res Method. 2008;8(1):1-10.

27. Edens GE. Professional Socialization in Nursing. Paper presented at the Annual Research in Nursing Education Conference, San Francisco, CA; 1987.

28. Weidman J. Undergraduate socialization: A conceptual approach. Higher education: Handbook of theory and research. 1989;5(2):289-322.

29. Weidman JC, Twale DJ \& Stein EL. Socialization of graduate and professional students in higher education: A perilous passage? ASHE-ERIC Higher Education Report 28 (3). Washington, DC: George Washington University, School of Education and Human Development. 2001.

30. Miller SE. A conceptual framework for the professional socialization of social workers. J Human Behav Social Environ. 2010;20(7):924-38.

31. Devenish A, Clark M, Fleming M. Experiences in becoming a paramedic: the professional socialization of university qualified paramedics. Creat Educ. 2016;7(6):786-801.

32. Perez RJ. A conceptual model of professional socialization within student affairs graduate preparation programs. J Study Postsecon Tertiary Educ. 2016 14;1:35-52.

33. Atherley AE, Hambleton IR, Unwin N, George C, Lashley PM, Taylor CG. Exploring the transition of undergraduate medical students into a clinical clerkship using organizational socialization theory. Perspect Med Educ. 2016;5(2):78-87. 
34. Byram JN. The professionalization of medical students: a longitudinal analysis of professional identity formation and professionalism perceptions in second and third year medical students (Doctoral dissertation). Indiana, USA: Indiana Univ.; 2017.

35. Kaplan A. The Conduct of Inquiry: Methodology for Behavioral Science. New Brunswick, NJ: Transaction Publishers; 1998; 269.

36. Fawcett J, Desanto-Madeya S. Contemporary Nursing Knowledge. Analysis and Evaluation of Nursing Models and Theories. $2^{\text {nd }}$ ed. F.A. Davis, Philadelphia, PA; 2005.

37. Youngblut JM. A consumer's guide to causal modeling: Part I. J Pediat Nurs. 1994;9(4):268-71.

38. Turban E, Sharda R, and Delen D. Decision Support and Business Intelligence Systems, $9^{\text {th }}$ ed. Upper Saddle River, NJ, USA: Prentice-Hall; 2011.

39. Dillon SM. Descriptive decision making: Comparing theory with practice. InProceedings of 33rd ORSNZ Conference, University of Auckland, New Zealand 1998 Aug 31.

40. Safiullin NZ, Safiullin BL. Static and dynamic models in economics. Journal of Physics: Conference Series. 2018;1015(3):032117.

41. Barretti M. What do we know about the professional socialization of our students? J Soc Work Educ. 2004;40(2):255-83.

42. Reutter L, Field PA, Campbell IE, Day R. Socialization into Nursing: Nursing Students as Learners. J Nurs Educ 1997; 36(4):149-55.

43. Bauer TN \& Erdogan B. "Organizational socialization: the effective on boarding of new employees". In: Zedeck S (Ed.), APA Handbook of Industrial and Organizational Psychology, Vol. 3, American Psychological Association, Washington, DC; 2011: 51-64.

44. Weidman JC, DeAngelo L, Bethea KA. Understanding student identity from a socialization perspective. New Directions Higher Educ. 2014;2014(166):43-51.

45. Pascarella ET, Terenzini PT. How College Affects Students: A Third Decade of Research. Volume 2. Jossey-Bass, An Imprint of Wiley. 10475 Crosspoint Blvd, Indianapolis, IN 46256; 2005 Feb.

46. Engberg ME. Educating the workforce for the 21st century: A cross-disciplinary analysis of the impact of the undergraduate experience on students' development of a pluralistic orientation. Res Higher Educ. 2007;48(3):283-317.

47. Ozaki CC. College impact theories past and present. New Directions for Community Colleges. 2016;2016(174):23-33.

48. Pike GR, Kuh GD, Gonyea RM. The relationship between institutional mission and students' involvement and educational outcomes. Res Higher Educ. 2003;44(2):241-61.

49. Weidman JC. Socialization of students in higher education: Organizational perspectives. The Sage handbook for research in education: Engaging ideas and enriching inquiry. 2006:253-62.

50. Wheeler JM. How do Social Work Students Develop their Professional Identity? (Doctoral dissertation, University of Plymouth); 2017.

51. Locklear CE. Professional socialization and identity development of social work students. Doctor of Social Work Banded Dissertations, 2017;10.

52. Domenici A, Donno F. Static and dynamic data models for the storage resource manager v2. $J$ Grid Comput. 2009;7(1):115-33.

53. Silveira GL, Campos LK, Schweller M, Turato ER, Helmich E, de Carvalho-Filho MA. "Speed up"! The influences of the hidden curriculum on the professional identity development of medical students. Health Prof Educ. 2019;5(3):198-209.

54. Fergus KB, Teale B, Sivapragasam M, Mesina O, Stergiopoulos E. Medical students are not blank slates: Positionality and curriculum interact to develop professional identity. Perspect Med Educ. 2018;7(1):5-7.

55. van den Broek WS, Wijnen-Meijer M, Ten Cate O, Van Dijk M. Medical students' preparation for the transition to postgraduate training through final year elective rotations. GMS j Med Educ. 2017;34(5):1-14.

56. Barone MA, Vercio C, Jirasevijinda T. Supporting the development of professional identity in the Millennial learner. Pediatrics. 2019;143(3):e20183988.

57. Higgs J. Professional socialisation. InEducating health professionals 2013 Jan 1 (pp. 83-92). 
58. Charmaz K. The power and potential of grounded theory. Medical Sociology Online. 2012;6(3):215.

59. Saldana J. The Coding Manual for Qualitative Researchers $2^{\text {nd }}$ Ed. London: Sage; 2013.

60. Long DN. Out of the silo: A qualitative study of paramedic transition to a specialist role in community paramedicine (Doctoral dissertation, Queensland University of Technology); 2017.

61. Sober E. The principle of parsimony. Br J Philos Sci. 19811;32(2):145-56.

62. Vandekerckhove J, Matzke D, Wagenmakers EJ. Model comparison and the principle of parsimony. eScholarship, University of California; 2015. P:300-19.

63. Perez RJ. Exploring developmental differences in students' sensemaking during the transition to graduate school. J College Stud Develop. 2016;57(7):763-77.

64. Baxter Magolda MB. Self-authorship: The foundation for twenty-first-century education. New Direct Teach learn. 2007;2007(109):69-83.

65. Hart AW. Leader succession and socialization: A synthesis. Rev Educl Res. 1991;61(4):451-74.

66. Heck RH. Organizational and professional socialization: Its impact on the performance of new administrators. The Urban Review. 1995;27(1):31-49. 